\title{
Insight into biochar properties and its cost analysis
}

\author{
Mohammad Boshir Ahmed, John L Zhou*, Huu Hao Ngo, Wenshan Guo
}

\section{School of Civil and Environmental Engineering, University of Technology Sydney, Broadway, NSW 2007, Australia}

Corresponding author:

Prof John Zhou

Tel: +61 295142023

Fax: +61295147803

Email: junliang.zhou@uts.edu.au

\section{Highlights}

- Modified biochar preparatory processes have been summarized together with improvement of surface functionalities.

- Modified biochar has enhanced sorptive capacity for contaminants.

- Continuous fixed bed column model has been examined with applications.

- Regeneration methods for modified biochar have been discussed.

- Future research directions for modified biochar have been proposed. 


\begin{abstract}
Biochars (BCs) are widely produced and used for the remediation of environmental contaminants as bio-sorbents. In this review, statistical analysis of different BC physicochemical properties was conducted. It was observed that woody materials are the most suitable for preparing BCs, among many other potential raw materials such as food wastes and agricultural materials. Basically, BCs are produced through a variety of thermal treatment processes between 300 and $900{ }^{\circ} \mathrm{C}$, among which slow pyrolysis is widely used due to its moderate operating conditions and optimization of BC yields. Hydrothermal carbonisation (HTC) is also an effective approach for BC production under certain conditions. As pyrolysis temperature is increased, the carbon content, ash content, surface area, and pore volume tend to be increased while the yield, hydrogen, oxygen, nitrogen content, and $\mathrm{H} / \mathrm{C}$ and $\mathrm{O} / \mathrm{C}$ molar ratios tend to decrease. The economic feasibility of BCs depends on a range of factors from raw material price to efficient production technologies. Thus, the overall cost equation of a pilot $\mathrm{BC}$ production plant together with the cost equation for $\mathrm{BC}$ regeneration has been proposed. The future research directions of BCs are also elaborated.
\end{abstract}

Keywords: Biochar; Biosorbent; Feedstocks; Cost analysis; Slow pyrolysis; Pilot plant 


\section{Contents}

1. Introduction

2. Physico-chemical properties of BCs

2.1. BC production technologies

2.2. Elemental composition of BCs

2.3. Surface area, pore volume, yield and ash content of BCs

2.4. Statistical analysis of BCs properties

2.5. Suitable feedstocks for BC preparation

3. Cost analysis of $\mathrm{BC}$ production

3.1. Feedstock purchase cost

3.2. Transport cost

3.3. Production cost

3.4 Maintenance and other cost

3.5. Labor cost

3.6. Storage cost

4. Regeneration cost

5. Overall cost analysis of a BC pilot plant

6. Future perspectives of BCs

7. Summary and conclusions

References

\section{Introduction}

$\mathrm{BC}$ is a carbon dominant product which is obtained when biomass feedstocks are heated at elevated temperature in a closed reactor with little or no oxygen present [1]. $\mathrm{BC}$ is an ancient material that has been widely used to bolster primarily soil fertility and crop production [2-4]. $\mathrm{BC}$ was initially viewed as a source of energy and can be burned to supply process energy, for 
water and gas purification [5], and as charcoal in home cooking. Other potential benefits including nitrate leaching [6-11], adsorption of inorganic and organic contaminants [1, 1214] and reduction of trace-gas emissions from soil and atmosphere $[6,8,10]$. BC has been found to reduce carbon and methane emissions and provide an efficacious solution to remove heavy metals from storm runoff. The knack of BCs to hoard carbon and other uses will not only depend on its physical and chemical properties, as it can be changed by the preparatory processes or through the choice of feedstocks, but will also depend on the technical and economic barriers of handling BCs $[15,16]$.

Different types of biomass feedstocks have been used for the production of BCs ranging from agricultural waste to timber based hard materials [17-22]. In order to produce BCs, these feedstocks are mainly converted using different thermal methods including slow and fast pyrolysis, gasification, hydrothermal treatment, carbonization and torrefaction [2325]. Pyrolysis process can be either slow $\left(<10{ }^{\circ} \mathrm{Cs}^{-1}\right)$ or fast $\left(>10^{\circ} \mathrm{Cs}^{-1}\right)$ [26]. Thermal treatment can be performed with different final temperatures and with different heating rates which are responsible for the quality and prices of the BCs $[16,27]$. In particular, the yield of BCs decreases with increasing the yield of gases as the temperature of the pyrolysis process is raised to high temperatures. Thus the pyrolysis temperature affects both the quantity and quality of BCs produced from a given quantity of feedstocks. The quality of BCs (e.g. surface area, pore volume) is low when pyrolysis temperatures is lower than $350{ }^{\circ} \mathrm{C}$, and is generally increased up to some point (depending on end use) as temperature is increased [28].

To date, there is a major gap in the literature on the analysis of overall $\mathrm{BC}$ production and regeneration cost. Only a few articles $[29,30]$ discussed BC production cost in a specified range. As $\mathrm{BC}$ is a powerful biosorbent with a wide range of applications, its overall cost should be fully analyzed. In this review, a conceptual model for cost analysis of a BC pilot plant was developed by reviewing and analyzing the published studies related to the potential cost effectiveness of BCs. The focus is also being given on (i) physico-chemical properties of 
BCs, (ii) different BC production technologies leading to suitable products, and (iii) analysis of overall cost equations for a pilot plant $\mathrm{BC}$ production and regeneration. It is expected that this review will help to consider cost analysis for a whole plant and to promote $\mathrm{BC}$ application at commercial scale.

\section{Physico-chemical properties of BCs}

The quality characteristics of BCs will change along several dimensions according to final pyrolysis temperature as well as the heating rate and residence time, and the type of raw materials. For example, the yield, surface area, pore volume, ash, elemental composition, viscosity, calorific value, and water content of BCs vary with pyrolysis temperature. In this section, the discussion is limited on the yield, surface area, pore volume, ash, and elemental composition of different BCs at different pyrolysis temperatures.

\subsection{BC production technologies}

A range of feedstocks (animal feedings, agricultural materials, woody materials, solid wastes, food wastes, animal litters) have been mainly utilized to produce BCs. BCs can be produced by pyrolysis [31-37] via slow pyrolysis [19, 21,38] or fast pyrolysis [39-41], gasification [42, 43], torrefaction [23], carbonization [44], flash carbonization [15,45], and hydrothermal carbonization (HTC) [25]. BCs produced by HTC method are sometimes called hydrochar. $\mathrm{BC}$ production technologies have already been described in detail [1, 46-49], and are summarized in Table 1.

To produce $\mathrm{BCs}$, the most widely used process is slow pyrolysis due to relatively high yields, and the fixed and operation cost of biomass pretreatment is $50 \%$ low than that of fast pyrolysis [50]. This is also called conventional carbonization and has been used for thousands

of years to produce charcoal. The knowledge about charcoal production and its properties has been accumulated over 38000 years [51]. Slow and intermediate pyrolysis processes are 
generally favored for $\mathrm{BC}$ production $[50,52-54]$. On the other hand, HTC process is attracting more attention due to its inherent advantage of using wet biomass $[55,56]$ and irregular surface with more oxygen-containing groups and higher cation exchange capacity (CEC) [57, 58]. Thus slow pyrolysis and HTC are two of the most efficient BC conversation technologies which can be used for a wide range of feedstocks [1]. A majority of BCs produced by HTC are more acidic than by pyrolysis $[55,59]$. One of the most important properties of HTC-BC is that it is easily biodegradable (dominated by alkyl moieties), whereas $\mathrm{BC}$ from slow pyrolysis is more stable (dominated by aromatics) in case of soil amendment as hydrochar has more nutrient retention capacity [56, 60]. Since HTC requires water, this may be a cost effective $\mathrm{BC}$ production method for feedstocks with high moisture content [61]. However, hydro-chars are not included in the "European Biochar Certificate" (EBC) standardization due to their different chemical properties including low total organic compound, high ash, low surface area, low porosity and high nutrient content $[60,62]$.

On the other hand, little data is available for carbonization, flash carbonization, torrefaction, fast pyrolysis and gasification as these technologies are commonly favored for bio-oil, solid fuel or synthetic gas yields. BC yields from fast pyrolysis and gasification processes are significantly lower compared to those of slow pyrolysis, flash carbonization, carbonization, hydrothermal and torrefaction, due to more gases being produced hence favoring the bio-oil or syn-gas production. Thus further use of BCs produced by other thermochemical technologies cannot be underestimated [1].

In general, the yield of $\mathrm{BC}$ on a dry ash free (daf) basis can be calculated using equation 1 in order to remove the effect of moisture and ash [63]:

$$
\mathrm{Y}_{\mathrm{BC}, \mathrm{daf}}(\mathrm{wt} . \% \text { daf })=100 \times\left(\mathrm{Y}_{\mathrm{BC}, \text { ad }}-\mathrm{A}\right) /(100-\mathrm{M}-\mathrm{A})
$$

where $\mathrm{Y}_{\mathrm{BC} \text {,ad }}$ represents $\mathrm{BC}$ yield on air-dried basis, while $\mathrm{M}$ and $\mathrm{A}$ (wt.\%) are the moisture and ash contents of feedstock, respectively. 


\subsection{Elemental composition of BCs}

BCs and bio-oil are joint products of a pyrolysis process, the latter not discussed here. Data on BCs physico-chemical properties, obtained from different feedstocks, were collected from published studies on pyrolysis (Supplementary Table S1), and these feedstocks can be classified as follows:

- Animal feedings including feed lot, timothy grass, buffalo weed, broiler litter, rice straw, Miscanthus sacchariflours, grass feedstocks and switch grass.

- Crop residues including giant reed, cottonseed hull, safflower seed, wheat residues, coconut coir, corn cobs and cotton stalk.

- Agricultural materials such as fescue straw, wheat straw, rapeseed plant and soybean Stover.

- Food wastes including orange peel and tea waste.

- Woody materials including pine wood, pine needles, pine shaving, oak wood, peanut shell, poplar wood, pitch pine, eucalyptus wood, hard wood, hickory wood, wood saw dust, bamboo and pepper wood.

- Animal litters including turkey litter, poultry litters, dairy, paved-feedlot, swine manure, cattle manure and dairy manure.

- Solid wastes including swine solid, sewage sludge, sludge, green waste, sugar beet tailing, sugarcane bagasse, forest residues, tire rubber, saw dust and algae.

As shown in Figure 1, the elemental compositions of BCs i.e. carbon, oxygen, hydrogen, and $\mathrm{H} / \mathrm{C}$ and $\mathrm{O} / \mathrm{C}$ molar ratios are plotted against the pyrolysis temperature. The results demonstrate that the carbon content tends to be enhanced with increasing pyrolytic temperature from $100^{\circ} \mathrm{C}$ to $950^{\circ} \mathrm{C}$. Similar results were obtained from the independent component analysis of carbon content with pyrolysis temperature using SPSS statistic software version 23 (Supplementary Table S2). The positive correlation value of carbon content (0.266) against pyrolysis temperature indicates that carbon content increases with 
increasing pyrolysis temperature. Conversely, hydrogen and oxygen contents were found to decrease with increasing pyrolysis temperature:

$$
\begin{aligned}
& H=-0.0078 x+6.80 ; r^{2}=0.654 ; P<0.0001 \\
& O=-0.0503 x+41.53 ; r^{2}=0.512 ; P<0.0001
\end{aligned}
$$

The $\mathrm{r}^{2}$ and $\mathrm{P}$ values demonstrate that pyrolysis temperature has a pronounced effect on hydrogen and oxygen content. The correlation values of hydrogen (-0.924) and oxygen (0.759) show a similar pattern, i.e. increasing temperature of pyrolysis led to reduction of hydrogen and oxygen content, based on correlation matrix (Supplementary Table S2).

In addition, the $\mathrm{H} / \mathrm{C}$ ratio has been used as a degree of carbonization due to hydrogen being primarily associated with the organic matter in biomass. This ratio also indicates that there are more alkyl groups present in $\mathrm{BCs}$ if this ratio becomes higher [1]. A higher $\mathrm{O} / \mathrm{C}$ ratio in BCs may be an indication of more oxygenated functional groups such as hydroxyl, carboxylate and carbonyl that can contribute to high $\mathrm{CEC}$ value of $\mathrm{BCs}[64,65]$, representing more negative surface charge of the BCs [66].

Figure $1 \mathrm{~b}$ shows the scatter plots of $\mathrm{H} / \mathrm{C}$ and $\mathrm{O} / \mathrm{C}$ molar ratio vs. temperature. The results reveal that both $\mathrm{H} / \mathrm{C}$ and $\mathrm{O} / \mathrm{C}$ molar ratios decreased with increasing pyrolysis temperate as follows:

$$
\begin{aligned}
& \mathrm{H} / \mathrm{C}=-0.0018 \mathrm{x}+1.144 ; \mathrm{r}^{2}=0.658 ; \mathrm{P}<0.0001 \\
& \mathrm{O} / \mathrm{C}=-0.0007 \mathrm{x}+0.593 ; \mathrm{r}^{2}=0.314 ; \mathrm{P}<0.0001
\end{aligned}
$$

The $\mathrm{r}^{2}$ values and very lower $\mathrm{P}$ values indicated that there is a significant negative relationship between $\mathrm{H} / \mathrm{C}$ and $\mathrm{O} / \mathrm{C}$ ratios with pyrolysis temperature. The correlation coefficient values of $\mathrm{H} / \mathrm{C}(-0.871)$ and $\mathrm{O} / \mathrm{C}(-0.594)$ also indicate that decrease in their molar ratios with increasing temperature of production (Supplementary Table S2).

\subsection{Surface area, pore volume, yield and ash content of BCs}


The surface area increases with the increases in the $\mathrm{BC}$ production temperature, due to the escape of volatile substances including cellulose, hemicelluloses, and lignin from biomass and thus format channel structures during pyrolysis [52, 53, 67]. These channel structures facilitate to improve the specific surface area and pore structure of BCs [68]. A decrease in pore size format internal pore structure and increase in porosity as a result of volatile release during carbonization can be observed in BCs [52].

Figure 2 shows the changes in surface area (SA), pore volume (PV) and yield with pyrolysis temperature. With the increase in pyrolysis temperature both surface area and pore volume of $\mathrm{BCs}$ are slightly increased with a positive correlation coefficient value (Supplementary Table S2). The significance (1-tailed) value of surface area (0.374) indicates that increase in surface area as the pyrolysis temperature goes up, while the yield of BCs decreases with the increases in pyrolysis temperature [27]. The relationship between pyrolysis temperature and yield can be represented as follows:

$$
\text { Yield }=-0.062 \mathrm{x}+71.83 ; \mathrm{r}^{2}=0.343 ; \mathrm{P}<0.0001
$$

The $\mathrm{r}^{2}$ value is not very high but the $\mathrm{P}$ value is significantly lower than 0.001 , suggesting statistically significant relationship between the yield and pyrolysis temperature. The correlation coefficient and significance (1-tailed) values of BC yield and surface area also confirm such a relationship (Supplementary Table S2). Thus, increase in pyrolysis temperate caused a decrease in yield and increase in surface area.

Ash content tended to be increased as pyrolysis temperature was increased (Supplementary Table S2). The correlation coefficient value of ash (0.456) indicates an increase in ash content with the increase in pyrolysis temperature, while an inverse relation between carbon content and ash content (-0.572) is observed.

The Kaiser-Meyer-Olkin (KMO) measure value (0.741) of sampling adequacy (Supplementary Table S3) indicates that there are strong relationships of the BCs physicochemical properties. The Eigenvalues from the independent component analysis (Table2) 
show that three components such as yield (5.25), pyrolysis temperature (2.05), and surface area (1.13) could explain $84.3 \%$ of the total cumulative variances. Individually, the yield explains $52.5 \%$ of total variances, while pyrolysis temperature accounts for $20.5 \%$ of total variances.

\subsection{Statistical analysis of BCs properties}

Statistical regression methods were used to analyze relationships among BCs properties, obtained from different feedstock's, by using SPSS. Table 3 provides the regression results for $\mathrm{BC}$ yield at $95 \%$ significance level i.e. $\mathrm{P}<0.05$, with $\mathrm{BC}$ yield as dependent variable as a percent of feedstock mass. This kind of regression analysis provides a foundation for understanding the choice of parameters. According to Table 3, the regression equation for $\mathrm{BC}$ yield at any given $\mathrm{BC}$ feedstock parameters can be written as:

$$
\begin{gathered}
\text { Yield }(\%)=10.468-0.019(\mathrm{~T})-0.013(\mathrm{SA})+0.247(\mathrm{C})-4.748(\mathrm{H})+0.032(\mathrm{O})+56.596(\mathrm{H} / \mathrm{C}) \\
+3.775(\mathrm{O} / \mathrm{C})+0.468(\mathrm{Ash})-2.426(\mathrm{~N})
\end{gathered}
$$

This equation can potentially provide a good fit for any parameter as listed in supplementary Table S1 under common operating conditions. The $r^{2}$ value 0.811 with an adjusted $r^{2}$ value 0.795 for BCs properties indicates a statistically significant relationship in the measurement. Other parameters such as pore volume, volatile matter, residence time, and $\mathrm{pH}$ were not included in regression analysis as those data are not available from literature, thus the accuracy of analysis may be reduced. For example, only 64 data were found on pore volume among the analysis of 202 datasets. Table 3shows that $\mathrm{H} / \mathrm{C}$ ratio $(0.000)$, ash (0.021) and $\mathrm{N}$ content (0.000) have a higher significance value at a significance level $\mathrm{P}<0.05$.

\subsection{Suitable feedstocks for BC preparation}

Supplementary Tables S1 and S4 show the descriptive statistics (mean, SD, max., min., mode, and median) of biomass feedstocks and types of feedstocks, respectively, for the production 
of BCs. Figure 3 shows that mean pyrolysis temperature for $\mathrm{BC}$ production is $486{ }^{\circ} \mathrm{C}$ with a yield of $41.3 \%$. The mean surface area and carbon content were found to be $88.15 \mathrm{~m}^{2} \mathrm{~g}^{-1}$ and $65.46 \%$, respectively.

Maximum mean yield (46.2\%) of BCs was found for solid wastes at a mean pyrolysis temperature of $587^{\circ} \mathrm{C}$. However, BCs derived from woody materials had a maximum mean surface area $\left(126.2 \mathrm{~m}^{2} \mathrm{~g}^{-1}\right)$ and maximum mean carbon content $(73.8 \%)$ at a minimum mean pyrolysis temperature of $440{ }^{\circ} \mathrm{C}$ with a mean yield of $41.7 \%$, which is almost the same as the mean yield (41.3\%) of all BCs materials (Supplementary Tables S1 and S4). The surface area and pore volume $\left(0.21 \mathrm{~cm}^{3} \mathrm{~g}^{-1}\right)$ of woody biomass derived BCs are higher than all other types of feedstock biomass with lower mean temperature indicating that more contaminants can be sorbed on BC surfaces. For example, BC produced at temperatures above $400{ }^{\circ} \mathrm{C}$ with high surface area is more effective than $\mathrm{BC}$ produced at below $400{ }^{\circ} \mathrm{C}$ in adsorbing contaminants such as heavy metals and organic pollutants from water $[47,48]$. Again, BCs derived from food wastes and woody materials have almost the same high mean $\mathrm{H} / \mathrm{C}$ and $\mathrm{O} / \mathrm{C}$ molar ratios which indicate that these kinds of materials contain higher alkyl as well as oxygenated groups in the core structures. Lower mean $\mathrm{O} / \mathrm{C}$ and $\mathrm{H} / \mathrm{C}$ molar ratio of crop residues derived $\mathrm{BC}$ indicates that lower functional group in the $\mathrm{BC}$ core structures. One of the main disadvantages of solid waste is that it has abnormally higher mean ash content (47\%) and higher mean nitrogen content $(2.4 \%)$. It is perhaps more clearly shown in Figure 3 that woody materials are most suitable for the production of BCs.

Figure 4 shows the variation of surface area, carbon content, hydrogen content and oxygen content against different feedstocks for preparing BCs at a pyrolysis temperature of $500{ }^{\circ} \mathrm{C}$. It can be seen that pine shaving, pine needles, wood, wheat residues, and giant reed derived BCs have shown the highest surface area and carbon content. It can be stated that mostly woody biomass has possessed key physico-chemical properties of BCs, and is thus best suited for converting to $\mathrm{BC}$ sorbents. Other materials such as food wastes and 
agricultural materials derived BCs have also good physico-chemical properties to be used as sorbents.

\section{Cost analysis of BC production}

The cost of BC production is a key component in the marketing and application of BCs. In cases where $\mathrm{BC}$ is the main product, the cost needs to cover operating expenses including production cost, maintenance cost, feedstock cost, transport cost, labour cost, distribution cost and others to ensure long-term business viability. In other cases, BC may be an ancillary byproduct from processes designed to create efficiencies in established agricultural or land management operations as well as heating systems. Whether BC is a main or by-product in any given operation, its value will be determined by the price customers are prepared to pay. It is economically equivalent to assume that the quality does not vary in terms of economic value over the feasible temperature range, or at least, that market prices would not vary according to quality [27].

There is currently no major industrial $\mathrm{BC}$ market from which to obtain $\mathrm{BC}$ price and cost data for a comprehensive estimation [29]. The unit cost $\mathrm{C}_{\mathrm{BC}}\left(\$\right.$ ton $\left.^{-1}\right)$ for producing and applying BCs in North Western Europe was calculated as follows:

$$
\mathrm{C}_{\mathrm{BC}}=\left(\mathrm{C}_{\mathrm{c}}+\mathrm{C}_{\mathrm{o}}+\mathrm{C}_{\mathrm{f}}+\mathrm{C}_{\mathrm{g}}+\mathrm{C}_{\mathrm{b}}-\mathrm{R}_{\mathrm{e}}\right) / \mathrm{W}+\mathrm{C}_{\mathrm{A}}
$$

where $C_{c}$ is the annualised capital expenditure of pyrolysis facility $\left(\$ y^{-1}\right), C_{o}$ is the total annual operating expenses of pyrolysis facility $\left(\$ \mathrm{y}^{-1}\right), \mathrm{C}_{\mathrm{f}}$ is the total annual cost of feedstock harvesting $\left(\$ \mathrm{y}^{-1}\right), \mathrm{C}_{\mathrm{g}}$ is the total annual cost of feedstock transport $\left(\$ \mathrm{y}^{-1}\right), \mathrm{C}_{\mathrm{b}}$ is the total annual cost of $\mathrm{BC}$ transport $\left(\$ \mathrm{y}^{-1}\right), \mathrm{R}_{\mathrm{e}}$ is the annual revenue from electricity generation $\left(\$ \mathrm{y}^{-1}\right)$, $\mathrm{W}$ is the annual $\mathrm{BC}$ production (ton $\left.\mathrm{y}^{-1}\right)$, and $\mathrm{C}_{\mathrm{A}}$ is the unit cost of $\mathrm{BC}$ application $\left(\$\right.$ ton $\left.^{-1}\right)$. Similarly BC production cost from forest chips can be represented as follow [69]:

$$
\mathrm{C}_{\mathrm{BC}}=\mathrm{C}_{\mathrm{Stump}}+\mathrm{C}_{\mathrm{FC} \text { prod }}+\mathrm{C}_{\mathrm{FC} \text { trans }}+\mathrm{C}_{\mathrm{CC} \text { prod }}
$$

where $\mathrm{C}_{\mathrm{BC}}$ is the unit cost of $\mathrm{BCs}, \mathrm{C}_{\mathrm{Stump}}$ is stumpage price, $\mathrm{C}_{\mathrm{FC}}$ prod is the production cost of forest chips (cutting, forwarding, chipping and overheads), $\mathrm{C}_{\mathrm{FC}}$ trans is forest chip road 
transportation cost and $\mathrm{C}_{\mathrm{CC} \text { prod }}$ is $\mathrm{BC}$ production stage cost. Additional cost might be required if feedstocks require intensive cleaning.

Up to 2013, a total of 43 companies have reported sales of BCs in various countries with listed mean prices for pure and blended BCs. Globally, the mean price for BCs was $\$ 2.65 \mathrm{~kg}^{-1}$; this ranged from as low as $\$ 0.09 \mathrm{~kg}^{-1}$ in the Philippines to as high as $\$ 8.85 \mathrm{~kg}^{-1}$ in the UK. For blended BCs the mean price was $\$ 3.29 \mathrm{~kg}^{-1}$ ranging from $\$ 0.08 \mathrm{~kg}^{-1}$ in India to $\$ 13.48 \mathrm{~kg}^{-1}$ in the US [30]. Therefore the market price of BCs is highly variable depending on the origin of $\mathrm{BC}$ production sites.

\subsection{Feedstock purchase cost}

Purchased biomass cost $\mathrm{C}_{\mathrm{PB}}\left(\$ \mathrm{y}^{-1}\right)$ can be determined as a function of the annual biomass flow rate $M_{A}$ (ton $\left.y^{-1}\right)$, and the specific purchased cost of biomass $C_{B}\left(\$\right.$ ton $\left.^{-1}\right)$ for producing $\mathrm{BC}$ in a plant which can be represented as follows:

$$
\mathrm{C}_{\mathrm{PB}}=\mathrm{M}_{\mathrm{A}} \times \mathrm{C}_{\mathrm{B}}
$$

where $\mathrm{M}_{\mathrm{A}}$ (ton $\mathrm{y}^{-1}$ ) is evaluated according to literature data [70]. Cost may vary depending on the types of feed-stocks. Table 4 listed some of the feedstock and production cost of BCs.

\subsection{Transport cost $\left(C_{T B}\right)$}

In many cases, transport cost of biomass can become substantial when the transportation distance becomes long from $\mathrm{BC}$ production plant [70]. Thus it is necessary to consider transport cost $\mathrm{C}_{\mathrm{TB}}\left(\$ \mathrm{y}^{-1}\right)$ which can be represented as follows:

$$
\mathrm{C}_{\mathrm{TB}}=\mathrm{C}_{\mathrm{V}}+\mathrm{C}_{\mathrm{TP}}
$$

where $C_{V}$ is the vehicles cost $\left(\$ y^{-1}\right)$ to bring feedstocks to $B C$ plant and $C_{T P}$ is the transportation personnel cost $\left(\$ \mathrm{y}^{-1}\right)$. Vehicles cost $\left(\mathrm{C}_{\mathrm{V}}\right)$ is the function of the total annual distance travelled $d_{T}\left(\mathrm{~km} \mathrm{y}^{-1}\right)$ and the specific vehicle transport cost $C_{\mathrm{VT}}\left(\$ \mathrm{y}^{-1}\right)$. Vehicle cost can be determined by the following equation: 


$$
\mathrm{C}_{\mathrm{V}}=\mathrm{d}_{\mathrm{T}} \times \mathrm{C}_{\mathrm{VT}}
$$

where $d_{T}$ can be calculated as the total number of travels required to transport the total amount

of biomass by resorting to vehicles having a capacity $\mathrm{V}_{\mathrm{C}}$ (ton vehicle ${ }^{-1}$ ), times the average round trip transportation distance. This can be calculated by assuming that the biomass is concentrated at $2 / 3$ of the radius of the catchment circular area necessary to produce the amount $\mathrm{M}_{\mathrm{A}}$ of biomass feeding the plant, starting from a uniform biomass distribution density $\mathrm{D}_{\mathrm{B}}\left(\right.$ ton $\left.\mathrm{km}^{-2} \mathrm{y}^{-1}\right)$. Therefore, $\mathrm{d}_{\mathrm{T}}$ can be estimated:

$$
d_{\mathrm{T}}=\frac{4}{3}\left(M_{A} / D_{B} \pi\right)^{0.5} \times\left(\frac{M_{A}}{V_{C}}\right)
$$

where the ratio $\mathrm{M}_{\mathrm{A}} / \mathrm{V}_{\mathrm{C}}$ represents the number of required travels.

As far as transportation personnel cost $\mathrm{C}_{\mathrm{TP}}\left(\$ \mathrm{y}^{-1}\right)$ is concerned a transport operation employed personnel fee $\left(\mathrm{C}_{\mathrm{PF}}\right)$ can be assumed and a number of operators employed in transport operations $\left(\mathrm{n}_{\mathrm{T}}\right)$ proportional to the number of required travels can be considered; thus the adopted equation for $\mathrm{T}_{\mathrm{P}}$ evaluation can be presented as:

$$
\mathrm{C}_{\mathrm{TP}}=\mathrm{C}_{\mathrm{PF}} \times \mathrm{n}_{\mathrm{T}}
$$

In addition, loading and unloading of the truck is incorporated into equation 15 [69]:

$$
\mathrm{C}_{\text {Trans }}=2.858+0.066 \mathrm{x}
$$

where $\mathrm{C}_{\text {Trans }}$ is road transportation cost in $\$ \mathrm{~m}^{-3}$ and $\mathrm{x}$ is road transportation distance in $\mathrm{km}$.

\subsection{Production cost}

Production cost is related to mainly equipment cost which is necessary for developing a BC plant. Total purchase of equipment $\operatorname{cost}\left(\mathrm{C}_{\mathrm{PE}}\right)$ can be calculated by considering the sum of the cost including pieces of equipment [70]. Purchased equipment cost for BC plant can be evaluated on the basis of correlations resulting from interpolation of experimental and literature data [73-75]. Equation 15 can be used for estimating $\mathrm{C}_{\mathrm{PE}}$ for $\mathrm{BC}$ production:

$$
\mathrm{C}_{\mathrm{PE}}=a \mathrm{~S}^{b}
$$


where $a$ and $b$ are the specific coefficients, while $\mathrm{S}$ is the characteristic equipment parameter. $\mathrm{C}_{\mathrm{PE}}$ is the function of the plant net electric power consumption and output, the biomass flow rate feeding to the reactor or combustor and others. The equipment purchase cost may vary according to the country of purchase, and the size and type of plant.

It was reported that a charcoal production stage (carbonization) cost $113 \$$ ton $^{-1}$ charcoal [44]. Production stage cost for three different sized BC production plants were studied [76]. Production stage cost including capital, storage, utility, labor and other plant cost ranged from 65 to $235 £ \operatorname{ton}^{-1}$ (98 to $353 \mathrm{USS} \mathrm{ton}^{-1}$ ) charcoal [69].

On a dry weight basis, if the yield of $\mathrm{BC}$ is assumed at $30 \%$ at any pyrolysis temperature then producing one tonne of charcoal from wood-based biomass requires almost 6.7 tonnes of raw material (wet weight basis, $50 \%$ moisture). It can be assumed that the volume would be around $7.8 \mathrm{~m}^{3}$ woods. It was found that the total forest chip cost was $24 € \mathrm{~m}^{-}$ ${ }^{3}\left(\$ 36 \mathrm{~m}^{-3}\right)$ and the total cost of raw materials delivered to the charcoal plant was $188 €$ ton $^{-1}$ $\left(\$ 283\right.$ ton $^{-1}$ ) charcoal. Charcoal production cost in many developed countries ranged roughly from 80 to $290 € \operatorname{ton}^{-1}$ ( $\$ 120$ to 436 ton $^{-1}$ ) charcoal $[44,76]$. Production costs and feedstock costs are shown in Table 4.

\subsection{Maintenance and other cost}

Maintenance cost $C_{\text {MAN }}\left(\$ y^{-1}\right)$ and insurance and general cost $C_{I \& G}\left(\$ y^{-1}\right)$ can be calculated as a percentage of total capital investment $\operatorname{cost}\left(\mathrm{C}_{\mathrm{TCI}}\right)$ as represented below:

$$
\begin{aligned}
& \mathrm{C}_{\mathrm{MAN}}=\mathrm{a}_{1} \times \mathrm{C}_{\mathrm{TCI}}=0.015 \mathrm{C}_{\mathrm{TCI}} \\
& \mathrm{C}_{\mathrm{I} \& \mathrm{G}}=\mathrm{b}_{1} \times \mathrm{C}_{\mathrm{TCI}}=0.01 \mathrm{C}_{\mathrm{TCI}}
\end{aligned}
$$

where $a_{1}$ and $b_{1}$ are the factors of some coefficients. The numerical values for equations 17 and 18 for such percentages can be found from literature data $[70,73,74]$ by assuming that $1.5 \%$ of $\mathrm{C}_{\mathrm{TCI}}$ and $1 \%$ of $\mathrm{C}_{\mathrm{TCI}}$, respectively for $\mathrm{C}_{\mathrm{MAN}}$ and $\mathrm{C}_{\mathrm{I} \& \mathrm{G}}$. 


\subsection{Labor cost}

Operating labor cost $C_{L}\left(\$ y^{-1}\right)$ can be estimated as a function of the employed personnel average fee $\left(\mathrm{C}_{\mathrm{PF}}\right)$ and the number of total annual working personnel $(\mathrm{n})$ involved $[70,73]$. This cost is also assumed to be variable with the plant size and depends on the country average labor cost as determined by country labor policy. Therefore, $\mathrm{C}_{\mathrm{L}}$ can be estimated:

$$
\mathrm{C}_{\mathrm{L}}=\mathrm{C}_{\mathrm{PF}} \times \mathrm{n}
$$

\subsection{Storage cost}

Biomass can be stored after collecting in several ways including on-plant open air, on-plant covered, or storage in a centralized covered facility. The storage cost $\left(\mathrm{C}_{\mathrm{S}}\right)$ is likely to depend on the volume of biomass and the length of time (t) that it has to be stored, the price of biomass, the quality of biomass required, and the weather conditions in the region.

$$
\mathrm{C}_{\mathrm{S}}=\mathrm{C}_{\mathrm{R}} \times \mathrm{t}
$$

where $C_{R}$ is the rent or unit price of the storage area.

\section{Regeneration process cost analysis}

To make the adsorption process more economical, it is necessary to regenerate the adsorbent.

A convenient and economical regeneration method can significantly reduce the cost of transportation and also the amount of wasted contaminant loaded adsorbent [78]. The adsorption-regeneration cycle can be repeated a few times which demonstrates that the adsorption capacity may drop slightly during regeneration cycle. The adsorption capacity always decline by the number of cycles. The sorption capacity and the removal efficiency can be calculated below [79-81]:

$$
\begin{aligned}
& \text { Removal efficeicy }(\%)=\frac{\mathrm{C}_{0}-\mathrm{C}_{\mathrm{t}}}{\mathrm{C}_{0}} \times 100 \\
& \text { Adsorption capacity, } \mathrm{q}_{\mathrm{t}}=\frac{\mathrm{C}_{0}-\mathrm{C}_{\mathrm{t}}}{\mathrm{m}} \times \mathrm{V}
\end{aligned}
$$


where $\mathrm{q}_{\mathrm{t}}\left(\mu \mathrm{g} \mathrm{g}^{-1}\right)$ is the amount of adsorbate onto the adsorbent at time $\mathrm{t}, \mathrm{C}_{0}$ and $\mathrm{C}_{\mathrm{t}}$ are the concentration of the adsorbate $\left(\mu \mathrm{g} \mathrm{L}^{-1}\right)$ at time 0 and any time $\mathrm{t} ; \mathrm{V}(\mathrm{L})$, and $\mathrm{m}(\mathrm{g})$ are the volume of the solution and the mass of adsorbent, respectively.

Some of the regeneration techniques include thermal regeneration [79], chemical and solvent regeneration [78, 82], microwave [82], microbiological, electrochemical, ultrasonic, and wet air oxidation regeneration method. Three thermal methods are available for the regeneration of carbonaceous materials namely (i) pyrolysis, (ii) pyrolysis-gasification and (iii) gasification [83]. If the solvent regeneration method is to be used then solvent consumption should be much less than that by water [84]. The widely used solvents for BC regeneration are solutions of $\mathrm{HCl}, \mathrm{NaOH}$, EDTA and $\mathrm{NaCl}[78,83]$. In the cases of microbiological, chemical and solvent regeneration techniques cost can be calculated by equation 23:

$$
\begin{gathered}
\mathrm{C}_{R}=\left(m_{R 1} \times P_{S 1}\right)+\left(m_{R 2} \times P_{S 2}\right)+\left(m_{R 3} \times P_{S 3}\right)+\ldots \ldots \ldots \ldots .+\left(m_{R n} \times P_{S n}\right) \\
=n \sum\left(m_{R n} \times P_{S n}\right)
\end{gathered}
$$

where $\mathrm{C}_{R}(\$)$ is the regeneration cost, $\mathrm{m}_{\mathrm{R} 1}, \mathrm{~m}_{\mathrm{R} 2}, \mathrm{~m}_{\mathrm{R} 3} \ldots \ldots \mathrm{m}_{\mathrm{Rn}}$ are the amount of solvent/ chemicals $(\mathrm{ml})$ which are required for the $1^{\text {st }}, 2^{\text {nd }}, 3^{\text {rd }} \ldots n^{\text {th }}$ cycles of the regeneration steps. $\mathrm{P}_{\mathrm{S} 1}, \mathrm{P}_{\mathrm{S} 2}, \mathrm{P}_{\mathrm{S} 3} \ldots \ldots \mathrm{P}_{\mathrm{Sn}}$ are the price of solvent $\left(\$ \mathrm{~L}^{-1}\right)$ and $\mathrm{n}$ is the fraction of price that varies with the parameters. As shown in Supplementary Figure S1, the removal efficiency of BCs decreased with each stage of regeneration, but still maintaining sufficient capacity $[78,79$, 81]. Other regeneration cost may include electrical and operation cost. The reduced column capacity could be a result of decreased available adsorption sites (i.e., blocking) and repulsion by the irreversibly sorbed contaminants from previous cycles.

\section{Overall cost analysis of a BC pilot plant}

The overall cost for $\mathrm{BC}$ production should include a variety of relevant cost components. The economic evaluation for plant configurations can be carried out on the basis of total capital 
investment $\left(\mathrm{C}_{\mathrm{TCI}}\right)$, total operating cost $\left(\mathrm{C}_{\mathrm{TOC}}\right)$ and from electricity consumption and output cost. More clearly, TCI cost can be calculated as sum of all direct and indirect plant cost involved in producing BC. Such a direct cost may include capital investment cost, equipment cost $\left(\mathrm{P}_{\mathrm{E}}\right)$, electrical cost, civil work cost, direct installation cost, auxiliary equipment and services cost, instrumentations cost and site preparation cost etc., while indirect cost (IC) cost of a plant may include engineering and start-up cost [70].

Piping cost (B), electrical cost (C) and civil works cost (D) cannot be estimated directly as it depends on many factor such as country policy, up to date equipment cost, engineering cost and others $[70,73,74]$. Finally direct installation $(E=x A)$, auxiliary services $(\mathrm{F}=\mathrm{yA})$, instrumentations and controls $(\mathrm{G}=\mathrm{zA})$, site preparation $(\mathrm{H}=\mathrm{mA})$, engineering $(\mathrm{K}$ $=\mathrm{nA})$ and start-up $(\mathrm{W}=\mathrm{oA})$ cost can be calculated as a percentage of total $\mathrm{P}_{\mathrm{E}}(\mathrm{A})$ and TCI cost.

A generic overall cost for $\mathrm{BC}$ plant can be represented as:

Total direct plant cost, $\mathrm{C}_{\mathrm{D}}=\mathrm{A}+\mathrm{B}+\mathrm{C}+\mathrm{D}+\mathrm{E}+\mathrm{F}+\mathrm{G}+\mathrm{H}$

$$
\begin{aligned}
& =\mathrm{A}+\mathrm{B}+\mathrm{C}+\mathrm{D}+\mathrm{xA}+\mathrm{yA}+\mathrm{zA}+\mathrm{mA} \\
& =\mathrm{B}+\mathrm{C}+\mathrm{D}+\mathrm{A}(1+\mathrm{x}+\mathrm{y}+\mathrm{z}+\mathrm{m})
\end{aligned}
$$

Total indirect plant cost, $\mathrm{C}_{\mathrm{I}}=\mathrm{K}+\mathrm{W}$

$$
\begin{aligned}
& =\mathrm{nA}+\mathrm{oA} \\
& =\mathrm{A}(\mathrm{n}+\mathrm{o})
\end{aligned}
$$

Total capital investment cost, $\mathrm{C}_{\mathrm{TCI}}=\mathrm{C}_{\mathrm{D}}+\mathrm{C}_{\mathrm{I}}$

$$
\begin{aligned}
& =B+C+D+A(1+x+y+z+m)+A(n+o) \\
& =B+C+D+A(1+x+y+z+m+n+o)
\end{aligned}
$$

where $\mathrm{x}, \mathrm{y}, \mathrm{z}, \mathrm{m}, \mathrm{n}$ and $\mathrm{o}$ are the coefficient variables depending on factors such as the country, policy and capacity of the BC plant. Bridgwater et al. [73] predicted the values of coefficients variables as $\mathrm{x}=0.30, \mathrm{y}=0.15, \mathrm{z}=0.10, \mathrm{~m}=0.10, \mathrm{n}=0.12$, and $\mathrm{o}=0.10$. Thus 
the total value of all variables will be $0.87(0.30+0.15+0.10+0.10+0.12+0.10)$. Hence the equation 26 can be converted:

$$
\begin{aligned}
& \mathrm{C}_{\mathrm{TCI}}=\mathrm{B}+\mathrm{C}+\mathrm{D}+\mathrm{A}(1+0.87) \\
& =\mathrm{B}+\mathrm{C}+\mathrm{D}+1.87 \mathrm{~A} \\
& \mathrm{C}_{\mathrm{TOC}}=\mathrm{C}_{\mathrm{L}}+\mathrm{C}_{\mathrm{S}}+\mathrm{C}_{\mathrm{PB}}+\mathrm{C}_{\mathrm{TB}}+\mathrm{C}_{\mathrm{MAN}}+\mathrm{C}_{\mathrm{I} \& \mathrm{G}}
\end{aligned}
$$

Thus the sum of equations 27 and 28 is equal to the total cost of a pilot plant BC production unit $\left(\mathrm{C}_{\mathrm{T}}=\mathrm{C}_{\mathrm{TCI}}+\mathrm{C}_{\mathrm{TOC}}\right)$. Other cost may include such as depreciation cost, feedstock processing (cutting, forwarding, chipping and overheads) and drying cost, annual increment cost of all these factors. In order to estimate the final cost of a BC plant, the revenue that will come from the main or by-product such as bio-oil needs to be excluded. In that case, the production cost of $\mathrm{BC}$ will reduce significantly. Thus overall cost equation of $\mathrm{BC}$ production can be written as follows:

$$
\mathrm{C}_{\mathrm{T}}=\mathrm{C}_{\mathrm{TCI}}+\mathrm{C}_{\mathrm{TOC}}-\text { Bio-oil }_{\text {Revenue }}
$$

\section{Future perspectives of BCs}

Emerging sorbents such as BCs face numerous challenges ranging from economical and environmentally-friendly production, to a lack of quantitative understanding of their impact on soil fertility, soil biota, water quality and the environment. Undoubtedly, BCs as a relatively new sorbent can have wide applications, for example, activated BCs could replace traditional activated carbon with equivalent or even greater sorption efficiency for various contaminants due to their cost-effective production from different biomass sources [85]. BCs have been successfully used in applications such as soil amendment, fuel cells, organic and inorganic contaminants removal, developing anodizing materials, and as catalyst for reforming and conditioning of syngas, upgrading bio-oil or biodiesel to potential fuels [48]. Depending on the end use, BCs should be modified to improve certain functions. Thus some of the future perspectives of BCs to be used as sorbents may include: 
o Study on the optimisation of price factor for maximum yield of BCs at an optimum pyrolysis temperature;

o Conduct commercial scale cost analysis of $\mathrm{BC}$ production plant;

O Modification of $\mathrm{BC}$ surfaces utilizing different modifying agents to achieve selectivity and optimum performance;

o Setting up supply chains for the continuous production of $\mathrm{BC}$ bio-sorbents;

o Application of BCs for sorbing emerging environmental contaminants such as new pesticides, pharmaceuticals and personal care products, and

o Comparing the cost and adsorption performance of BCs with other adsorbents such as activated carbon, CNTs, graphite and clay minerals.

\section{Summary and conclusions}

This review focused on statistical independent component and regression analysis of $\mathrm{BC}$ production technologies and physico-chemical properties of different -BCs. It was observed that raw woody materials were the best which possess essential BC physic-chemical properties such as surface area and elemental composition. Other raw materials such as food waste and agricultural materials also potentially used for producing BCs with good physicchemical properties. Some feedstocks such as pine shaving, pine needles, wood, wheat residues, and giant reed showed high surface area and carbon content at a pyrolysis temperature of $500^{\circ} \mathrm{C} . \mathrm{BCs}$ produced through slow pyrolysis are widely used. A detailed pilot plant-based cost equation for $\mathrm{BC}$ production has been described. An equation for the cost analysis of $\mathrm{BCs}$ regeneration has been suggested with very high regeneration efficiency. Some of the future perspectives have been proposed for the research in the field of BC's applications.

\section{Acknowledgement}


We would like to thank the Faculty of Engineering and IT, University of Technology Sydney for a scholarship to M.B. Ahmed.

\section{Appendix A. Supplementary data}

Supplementary data related to this article can be found as attached. 


\section{References}

[1] Tan X, Liu Y, Zeng G, Wang X, Hu X, Gu Y, Yang Z. Application of biochar for the removal of pollutants from aqueous solutions. Chemosphere 2015; 125: 70-85.

[2] Lehmann J, Joseph S. 2012: Biochar for Environmental Management: Science and Technology. Routledge.

[3] Shackley S, Sohi S, Brownsort P, Carter S, Cook J, Cunningham C, Gaunt J, Hammond J, Ibarrola R, Mašek O. 2010: An assessment of the benefits and issues associated with the application of biochar to soil. Department for Environment, Food and Rural Affairs, UK Government, London.

[4] Sohi S, Krull E, Lopez-Capel E, Bol R. A review of biochar and its use and function in soil. Adv Agron 2010; 105: 47-82.

[5] Ayhan D, Pehlivan E, Altun T. Potential evolution of Turkish agricultural residues as biogas, bio-char and bio-oil sources. Inter J Hydrogen Energ 2006; 31(5): 613-620.

[6] Clough TJ, Bertram JE, Ray J, Condron LM, O'Callaghan M, Sherlock RR, Wells N. Unweathered wood biochar impact on nitrous oxide emissions from a bovine-urine-amended pasture soil. Soil Sci Soc Am J 2010; 74(3): 852-860.

[7] Lehmann J, da Silva Jr JP, Steiner C, Nehls T, Zech W, Glaser B. Nutrient availability and leaching in an archaeological Anthrosol and a Ferralsol of the Central Amazon basin: fertilizer, manure and charcoal amendments. Plant Soil 2003; 249(2): 343-357.

[8] Singh BP, Hatton BJ, Singh B, Cowie AL, Kathuria A. Influence of biochars on nitrous oxide emission and nitrogen leaching from two contrasting soils. J Environ Qual 2010; 39(4): 1224-1235.

[9] Steiner C, Teixeira WG, Lehmann J, Nehls T, de Macêdo JLV, Blum WE, Zech W. Long term effects of manure, charcoal and mineral fertilization on crop production and fertility on a highly weathered Central Amazonian upland soil. Plant Soil 2007; 291(1-2): 275-290. 
[10] Van Zwieten L, Kimber S, Morris S, Chan K, Downie A, Rust J, Joseph S, Cowie A. Effects of biochar from slow pyrolysis of papermill waste on agronomic performance and soil fertility. Plant Soil 2010; 327 (1-2): 235-246.

[11] Van Zwieten L, Kimber S, Morris S, Downie A, Berger E, Rust J, Scheer C. Influence of biochars on flux of $\mathrm{N}_{2} \mathrm{O}$ and $\mathrm{CO}_{2}$ from Ferrosol. Soil Res 2010; 48(7): 555-568.

[12] Beesley L, Moreno-Jiménez E, Gomez-Eyles JL. Effects of biochar and greenwaste compost amendments on mobility, bioavailability and toxicity of inorganic and organic contaminants in a multi-element polluted soil. Environ Pollut 2010; 158: 2282-2287.

[13] Mohan D, Sarswat A, Ok YS, Pittman CU. Organic and inorganic contaminants removal from water with biochar, a renewable, low cost and sustainable adsorbent-a critical review. Bioresour Technol 2014: 160: 191-202.

[14] Zheng H, Wang Z, Zhao J, Herbert S, Xing B. Sorption of antibiotic sulfamethoxazole varies with biochars produced at different temperatures. Environ Pollut 2013; 181: 60-67.

[15] Meyer S, Glaser B, Quicker P. Technical, economical, and climate-related aspects of biochar production technologies: a literature review. Environ Sci Technol 2011; 45(22): 94739483.

[16] Pratt K, Moran D. Evaluating the cost-effectiveness of global biochar mitigation potential. Biomass Bioenerg 2010; 34(8): 1149-1158.

[17] Ahmad M, Lee SS, Rajapaksha AU, Vithanage M, Zhang M, Cho JS, Lee SE, Ok YS. Trichloroethylene adsorption by pine needle biochars produced at various pyrolysis temperatures. Bioresour Technol 2013; 143: 615-622.

[18] Chen T, Zhang Y, Wang H, Lu W, Zhou Z, Zhang Y, Ren L. Influence of pyrolysis temperature on characteristics and heavy metal adsorptive performance of biochar derived from municipal sewage sludge. Bioresour Technol 2014; 164: 47-54. 
[19] Sun Y, Gao B, Yao Y, Fang J, Zhang M, Zhou Y, Chen H, Yan L. Effects of feedstock type, production method, and pyrolysis temperature on biochar and hydrochar properties. Chem Eng J 2014; 240: 574-578.

[20] Tsai WT, Chen HR. Adsorption kinetics of herbicide paraquat in aqueous solution onto a low-cost adsorbent, swine-manure-derived biochar. Int J Environ Sci Technol 2013; 10(6): $1349-1356$.

[21] Wang Z, Zheng H, Luo Y, Deng X, Herbert S, Xing B. Characterization and influence of biochars on nitrous oxide emission from agricultural soil. Environ Pollut 2013; 174: 289-296.

[22] Xu G, Yang X, Spinosa L. Development of sludge-based adsorbents: Preparation, characterization, utilization and its feasibility assessment. J Environ Manag 2015; 151: 221 232.

[23] Jung C, Boateng LK, Flora JR, Oh J, Braswell MC, Son A, Yoon Y. Competitive adsorption of selected non-steroidal anti-inflammatory drugs on activated biochars: Experimental and molecular modeling study. Chem Eng J 2015; 264: 1-9.

[24] Mimmo T, Panzacchi P, Baratieri M, Davies C, Tonon G. Effect of pyrolysis temperature on miscanthus (Miscanthus $\times$ giganteus) biochar physical, chemical and functional properties. Biomass Bioenerg 2014; 62: 149-157.

[25] Parshetti GK, Hoekman SK, Balasubramanian R. Chemical, structural and combustion characteristics of carbonaceous products obtained by hydrothermal carbonization of palm empty fruit bunches. Bioresour Technol 2013; 135: 683-689.

[26] Bridgwater A, Meier D, Radlein D. An overview of fast pyrolysis of biomass. Org Geochem 1999; 30: 1479-1493.

[27] Yoder J, Galinato S, Granatstein D, Garcia-Pérez M. Economic tradeoff between biochar and bio-oil production via pyrolysis. Biomass Bioenerg 2011: 35(5): 1851-1862.

[28] Angin D. Effect of pyrolysis temperature and heating rate on biochar obtained from pyrolysis of safflower seed press cake. Bioresour Technol 2013; 128: 593-597. 
[29] Dickinson D, Balduccio L, Buysse J, Ronsse F, Huylenbroeck G, Prins W. Cost-benefit analysis of using biochar to improve cereals agriculture. GCB Bioenergy 2014; 7(4): 850-864. [30] Jirka S, Tomlinson T. State of the Biochar Industry-A survey of commercial activity in the biochar field. A report by the International Biochar Initiative (IBI) 2013; 61 .

[31] Chen C, Zhou W, Lin D. Sorption characteristics of N-nitrosodimethylamine onto biochar from aqueous solution. Bioresour Technol 2015; 179: 359-366.

[32] Genovese M, Jiang J, Lian K, Holm N. High capacitive performance of exfoliated biochar nanosheets from biomass waste corn cob. J Mater Chem A 2015; 3(6): 2903-2913.

[33] Herath H, Camps-Arbestain M, Hedley M. Effect of biochar on soil physical properties in two contrasting soils: An Alfisol and an Andisol Geoderma 2013; 209: 188-197.

[34] Mendez A, Paz-Ferreiro J, Araujo F, Gascó G. Biochar from pyrolysis of deinking paper sludge and its use in the treatment of a nickel polluted soil. J Anal Appl Pyrol 2014; 107: 4652.

[35] Mohanty P, Nanda S, Pant KK, Naik S, Kozinski JA, Dalai AK. Evaluation of the physiochemical development of biochars obtained from pyrolysis of wheat straw, timothy grass and pinewood: effects of heating rate. J Anal Appl Pyrol 2013; 104: 485-493.

[36] Veksha A, McLaughlin H, Layzell DB, Hill JM. Pyrolysis of wood to biochar: Increasing yield while maintaining microporosity. Bioresour Technol 2014; 153: 173-179.

[37] Yuan H, Lu T, Wang Y, Huang H, Chen Y. Influence of pyrolysis temperature and holding time on properties of biochar derived from medicinal herb (radix isatidis) residue and its effect on soil CO 2 emission. J Anal Appl Pyrol 2014; 110: 277-284.

[38] Liu Y, Zhao X, Li J, Ma D, Han R. Characterization of bio-char from pyrolysis of wheat straw and its evaluation on methylene blue adsorption. Desalination Water Treat 2012; 46(13): $115-123$. 
[39] Essandoh M, Kunwar B, Pittman CU, Mohan D, Mlsna T. Sorptive removal of salicylic acid and ibuprofen from aqueous solutions using pine wood fast pyrolysis biochar. Chem Eng J 2015; 265: 219-227.

[40] Kim KH, Kim JY, Cho TS, Choi JW. Influence of pyrolysis temperature on physicochemical properties of biochar obtained from the fast pyrolysis of pitch pine (Pinus rigida). Bioresour Technol 2012; 118: 158-162.

[41] Liu P, Liu WJ, Jiang H, Chen JJ, Li WW, Yu HQ. Modification of bio-char derived from fast pyrolysis of biomass and its application in removal of tetracycline from aqueous solution. Bioresour Technol 2012; 121: 235-240.

[42] Fu P, Hu S, Xiang J, Yi W, Bai X, Sun L, Su S. Evolution of char structure during steam gasification of the chars produced from rapid pyrolysis of rice husk. Bioresour Technol 2012; 114: 691-697.

[43] Yuan S, Dai ZH, Zhou ZJ, Chen XL, Yu GS, Wang FC. Rapid co-pyrolysis of rice straw and a bituminous coal in a high-frequency furnace and gasification of the residual char. Bioresour Technol 2012; 109: 188-197.

[44] Norgate T, Langberg D. Environmental and economic aspects of charcoal use in steelmaking. ISIJ Int 2009; 49(4): 587-595.

[45] Antal MJ, Mochidzuki K, Paredes LS. Flash carbonization of biomass. Indust Eng Chem Res 2003; 42: 3690-3699.

[46] Ahmad M, Rajapaksha AU, Lim JE, Zhang M, Bolan N, Mohan D, Vithanage M, Lee SS, Ok YS. Biochar as a sorbent for contaminant management in soil and water: a review. Chemosphere 2014; 99: 19-33.

[47] Kong SH, Loh SK, Bachmann RT, Rahim SA, Salimon J. Biochar from oil palm biomass: A review of its potential and challenges. Renew Sustain Energ Rev 2014; 39: 729739. 
[48] Qian K, Kumar A, Zhang H, Bellmer D, Huhnke R. Recent advances in utilization of biochar. Renew Sustain Energ Rev 2015; 42: 1055-1064.

[49] Xie T, Reddy KR, Wang C, Yargicoglu E, Spokas K. Characteristics and Applications of Biochar for Environmental Remediation: a review. Crit Rev Environ Sci Technol 2014; 45(9): 939-969.

[50] Brown R. 2009: Biochar production technology. In Biochar for Environmental Management: Science and Technology, edited by J. Lehmann and S. Joseph, Earthscan, London, pp. 127-146.

[51] Antal MJ, Grønli M. The art, science, and technology of charcoal production. Indust Eng Chem Res 2003; 42(8): 1619-1640.

[52] Ahmad M, Lee SS, Dou X, Mohan D, Sung JK, Yang JE, Ok YS. Effects of pyrolysis temperature on soybean stover-and peanut shell-derived biochar properties and TCE adsorption in water. Bioresour Technol 2012; 118: 536-544.

[53] Chen Y, Yang H, Wang X, Zhang S, Chen H. Biomass-based pyrolytic polygeneration system on cotton stalk pyrolysis: influence of temperature. Bioresour Technol 2012; 107: 411-418.

[54] Yao Y, Gao B, Inyang M, Zimmerman AR, Cao X, Pullammanappallil P, Yang L. Biochar derived from anaerobically digested sugar beet tailings: characterization and phosphate removal potential. Bioresour Technol 2011; 102(10): 6273-6278.

[55] Kumar S, Loganathan VA, Gupta RB, Barnett MO. An assessment of U (VI) removal from groundwater using biochar produced from hydrothermal carbonization. J Environ Manage 2011; 92(10): 2504-2512.

[56] Malghani S, Gleixner G, Trumbore SE. Chars produced by slow pyrolysis and hydrothermal carbonization vary in carbon sequestration potential and greenhouse gases emissions. Soil Biol Biochem 2013; 62: 137-146. 
[57] Huff MD, Kumar S, Lee JW. Comparative analysis of pinewood, peanut shell, and bamboo biomass derived biochars produced via hydrothermal conversion and pyrolysis. $\mathbf{J}$ Environ Manag 2014; 146: 303-308.

[58] Liu Z, Zhang FS. Removal of lead from water using biochars prepared from hydrothermal liquefaction of biomass. J Hazard Mater 2009; 167(1): 933-939.

[59] Kalderis D, Kotti M, Méndez A, Gascó G. Characterization of hydrochars produced by hydrothermal carbonization of rice husk. Solid Earth 2014; 5(1): 477-483.

[60] Wiedner K, Rumpel C, Steiner C, Pozzi A, Maas R, Glaser B. Chemical evaluation of chars produced by thermochemical conversion (gasification, pyrolysis and hydrothermal carbonization) of agro-industrial biomass on a commercial scale. Biomass Bioenerg 2013; 59: 264-278.

[61] Titirici MM, White RJ, Falco C, Sevilla M. Black perspectives for a green future: hydrothermal carbons for environment protection and energy storage. Energ Environ Sci 2012; 5(5): 6796-6822.

[62] Kambo H S, Dutta A. A comparative review of biochar and hydrochar in terms of production, physic-chemical properties and applications. Renew Sustain Energ Rev 2015; 45: $359-378$.

[63] Lee Y, Park J, Ryu C, Gang KS, Yang W, Park YK, Jung J, Hyun S. Comparison of biochar properties from biomass residues produced by slow pyrolysis at $500 \mathrm{C}$. Bioresour Technol 2013; 148: 196-201.

[64] Lee JW, Kidder M, Evans BR, Paik S, Buchanan Iii A, Garten CT, Brown RC. Characterization of biochars produced from cornstovers for soil amendment. Environ Sci Technol 2010; 44(20): 7970-7974.

[65] Yuan JH, Xu RK, Zhang H. The forms of alkalis in the biochar produced from crop residues at different temperatures. Bioresour Technol 2011; 102(3): 3488-3497. 
[66] Jiang TY, Jiang J, Xu RK, Li Z. Adsorption of $\mathrm{Pb}$ (II) on variable charge soils amended with rice-straw derived biochar. Chemosphere 2012; 89(3): 249-256.

[67] Kim WK, Shim T, Kim YS, Hyun S, Ryu C, Park YK, Jung J. Characterization of cadmium removal from aqueous solution by biochar produced from a giant Miscanthus at different pyrolytic temperatures. Bioresour Technol 2013; 138: 266-270.

[68] Li M, Liu Q, Guo L, Zhang Y, Lou Z, Wang Y, Qian G. Cu (II) removal from aqueous solution by Spartina alterniflora derived biochar. Bioresour Technol 2013; 141: 83-88.

[69] Suopajärvi H, Fabritius T. Towards more sustainable ironmaking - an analysis of energy wood availability in Finland and the economics of charcoal production. Sustainability 2013; 5(3): 1188-1207.

[70] Caputo AC, Palumbo M, Pelagagge PM, Scacchia F. Economics of biomass energy utilization in combustion and gasification plants: effects of logistic variables. Biomass Bioenerg 2005; 28(1): 35-51.

[71] Brown TR, Wright MM, Brown RC. Estimating profitability of two biochar production scenarios: slow pyrolysis vs fast pyrolysis. Biofuel Bioprod Bioref 2011; 5(1): 54-68.

[72] Roberts KG, Gloy BA, Joseph S, Scott NR, Lehmann J. Life cycle assessment of biochar systems: Estimating the energetic, economic and climate change potential. Environ Sci Technol 2009; 44(2): 827-833.

[73] Bridgwater A, Toft A, Brammer J. A techno-economic comparison of power production by biomass fast pyrolysis with gasification and combustion. Renew Sustain Energ Rev 2002; 6: $181-246$

[74] Peters MS, Timmerhaus KD.2003: Plant Design and Economics for Chemical Engineers. McGraw-Hill Education Europe.

[75] Turton R, Bailie RC, Whiting WB, Shaeiwitz JA. 2008: Analysis, Synthesis and Design of Chemical Processes. Pearson Education. 
[76] Shackley S, Hammond J, Gaunt J, Ibarrola R. The feasibility and cost of biochar deployment in the UK. Carbon Manag 2011; 2(3): 335-356.

[77] Fornes F, Belda RM, Lidón A. Analysis of two biochars and one hydrochar from different feedstock: focus set on environmental, nutritional and horticultural considerations. $\mathbf{J}$ Clean Prod 2015; 86, 40-48.

[78] Wang S Y, Tang Y K, Chen C, Wu J T, Huang Z, Mo Y Y, Chen J B. Regeneration of magnetic biochar derived from eucalyptus leaf residue for lead (II) removal. Bioresour Technol 2015; 186: 360-364.

[79] Shang J, He W, Fan C. Adsorption of dimethyl trisulfide from aqueous solution on a low-cost adsorbent: thermally activated pinecone. Chin J Oceanol Limn 2015; 33(1): 169175.

[80] Matatov-Meytal YI, Sheintuch M. Abatement of pollutants by adsorption and oxidative catalytic regeneration. Indust Eng Chem Res 1997; 36(10): 4374-4380.

[81] Nassar N N. Rapid removal and recovery of $\mathrm{Pb}$ (II) from wastewater by magnetic nanoadsorbents. J Hazard Mater 2010; 184(1): 538-546.

[82] Zhang X, Mao G, Jiao Y, Shang Y, Han R. Adsorption of anionic dye on magnesium hydroxide-coated pyrolytic bio-char and reuse by microwave irradiation. Intern J Environ Sci Technol 2014; 11 (5): 1439-1448.

[83] Ahmed MB, Zhou JL, Ngo HH, Guo W. Adsorptive removal of antibiotics from water and wastewater: progress and challenges. Sci Total Environ 2015; 532: 112-126.

[84] Tamon H, Saito T, Kishimura M, Okazaki M, Toei R. Solvent regeneration of spent activated carbon in wastewater treatment. J Chem Eng Japan 1990; 23(4): 426-432. [85] Ahmad M, Moon DH, Vithanage M, Koutsospyros A, Lee SS, Yang JE, Lee SE, Jeon C, Ok YS. Production and use of biochar from buffalo-weed (Ambrosia trifida L.) for trichloroethylene removal from water. J Chem Technol Biotech 2014; 89: 150-157. 


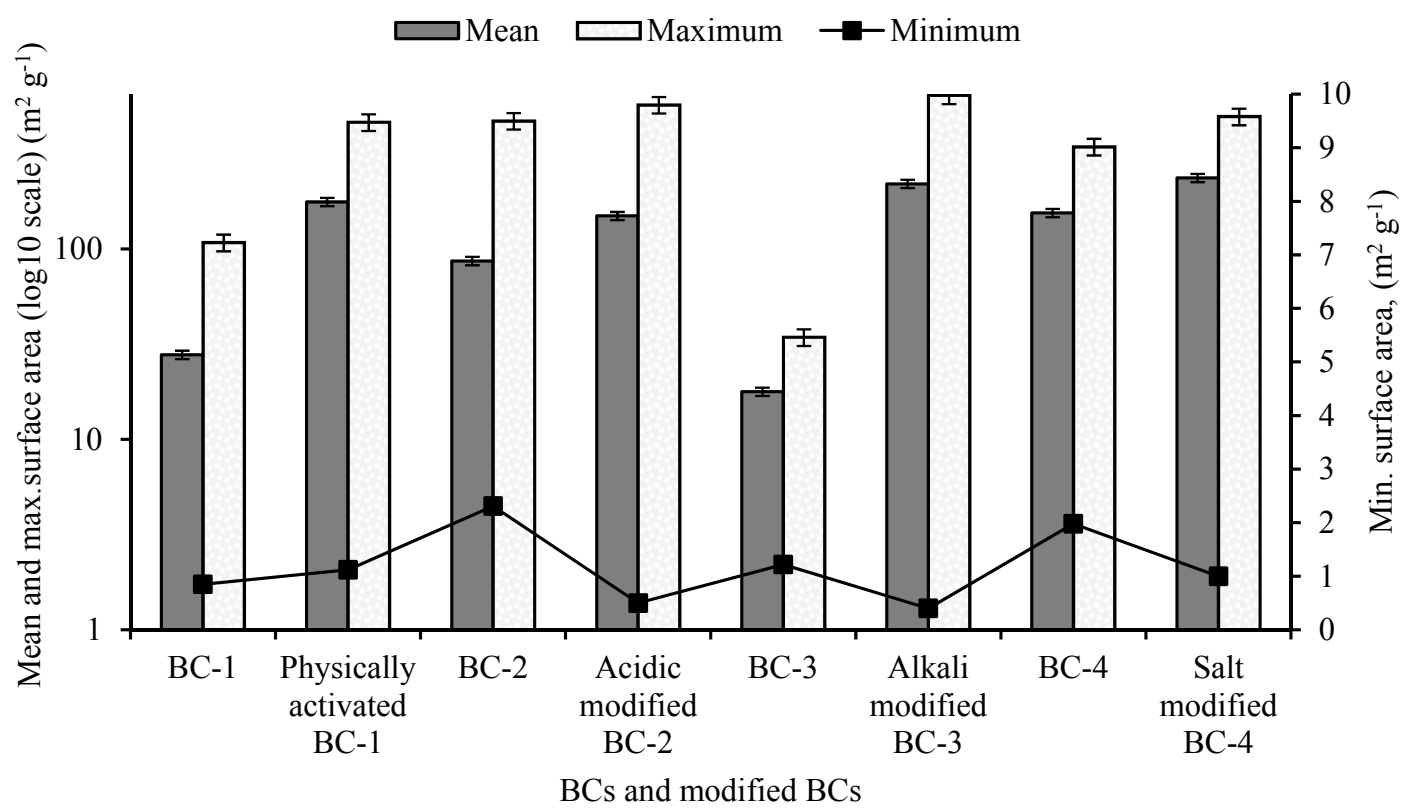

Figure 1: Mean, maximum and minimum values of surface area of BCs and modified BCs (numbers 1, 2, $3 \& 4$ represent the raw $\mathrm{BCs}$ and its corresponding modified $\mathrm{BCs}$ ).

ロ\%

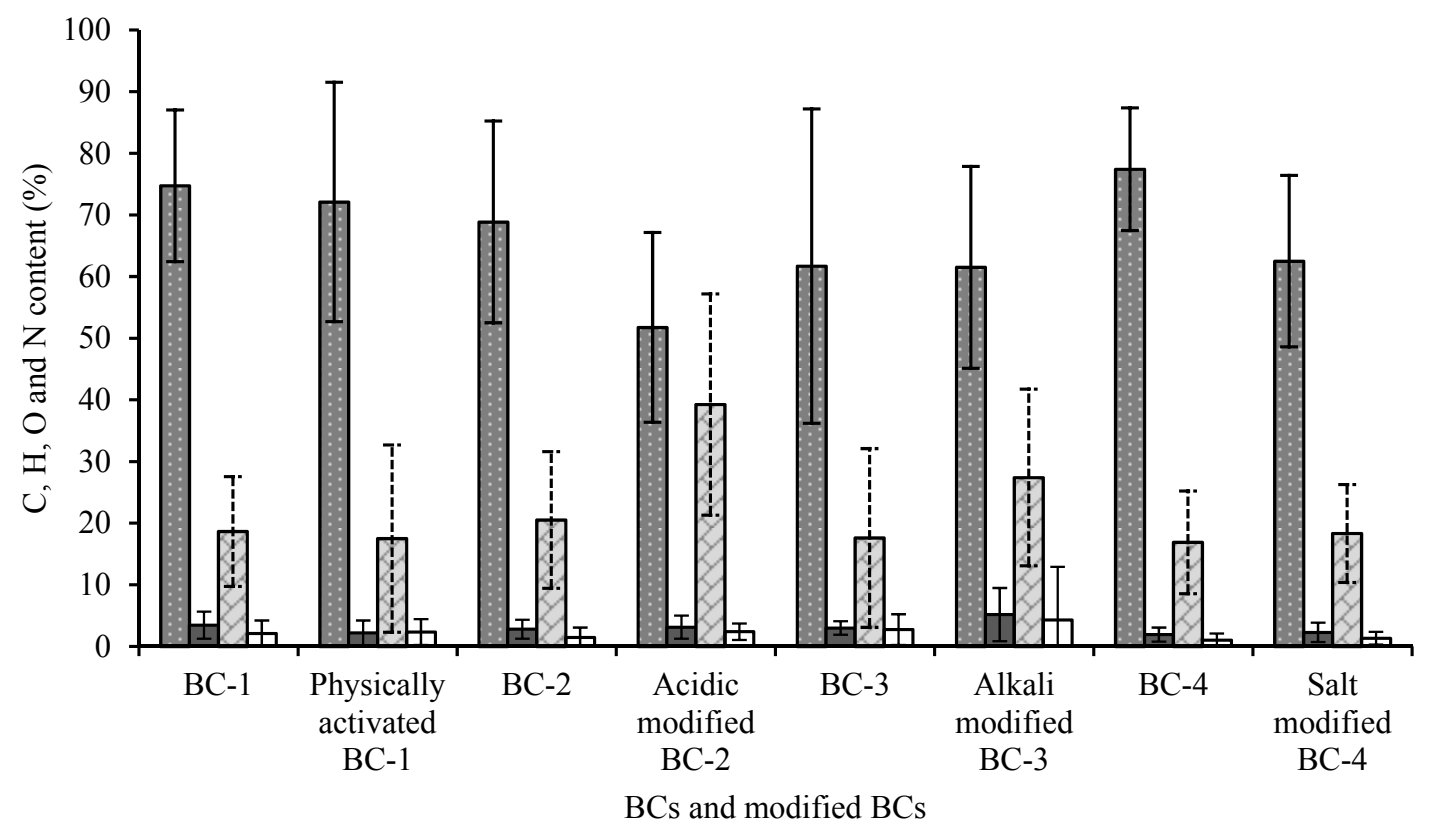

Figure 2: Mean value with standard deviation of $\mathrm{C}, \mathrm{H}, \mathrm{O}$ and $\mathrm{N}$ content $(\%)$ in $\mathrm{BCs}$ and modified BCs. 


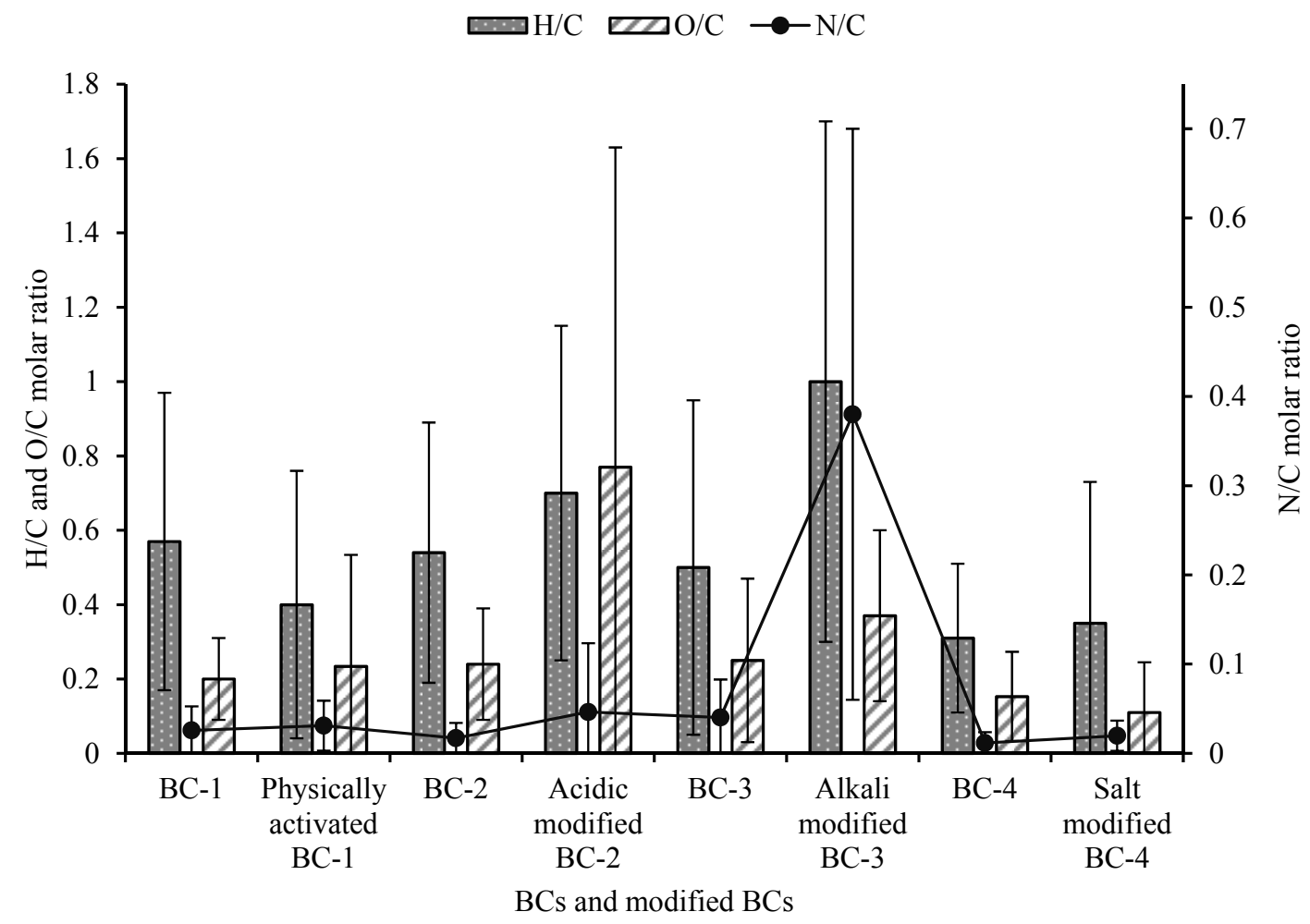

Figure 3: Mean value with standard deviation of $\mathrm{H} / \mathrm{C}, \mathrm{O} / \mathrm{C}$ and $\mathrm{N} / \mathrm{C}$ molar ratio of $\mathrm{BCs}$ and modified BCs.

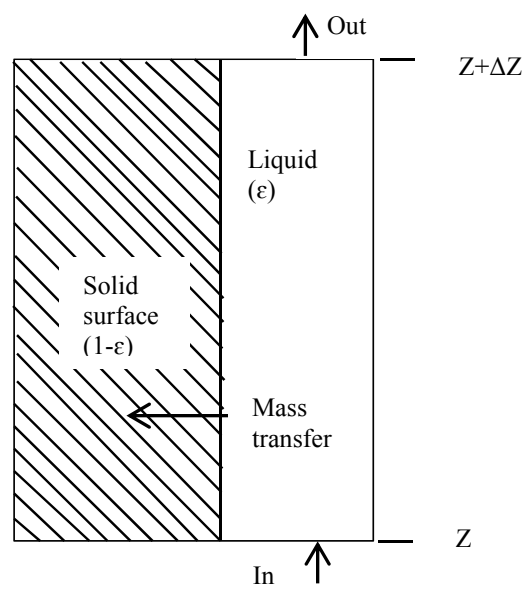

Figure 4. A schematic diagram of a section of a fixed -bed adsorption column 


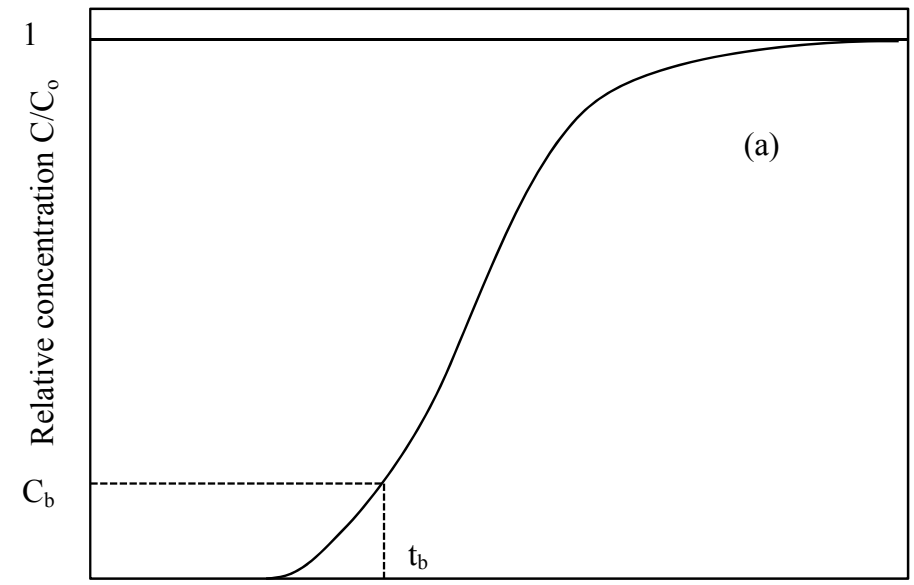

Time (min)
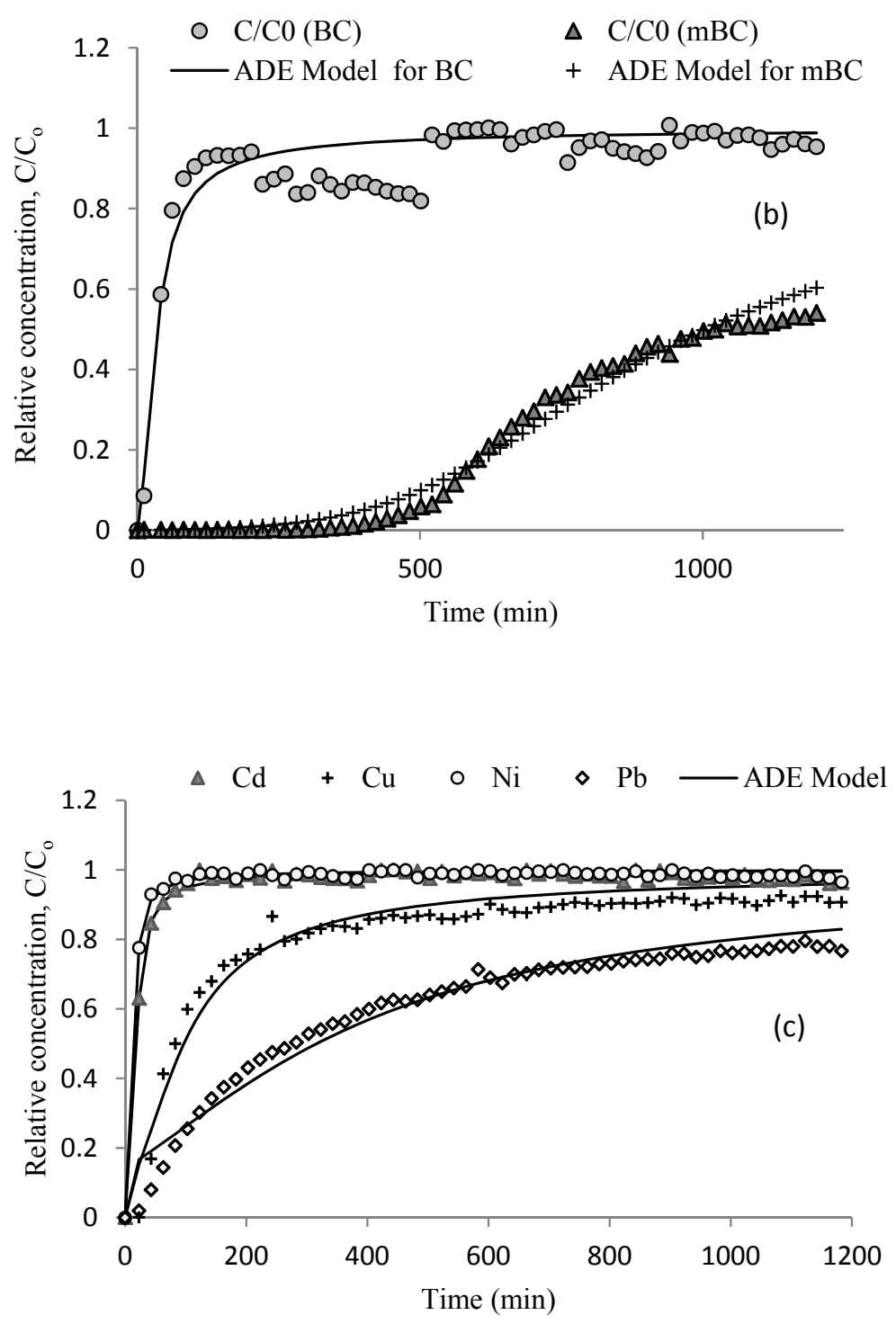

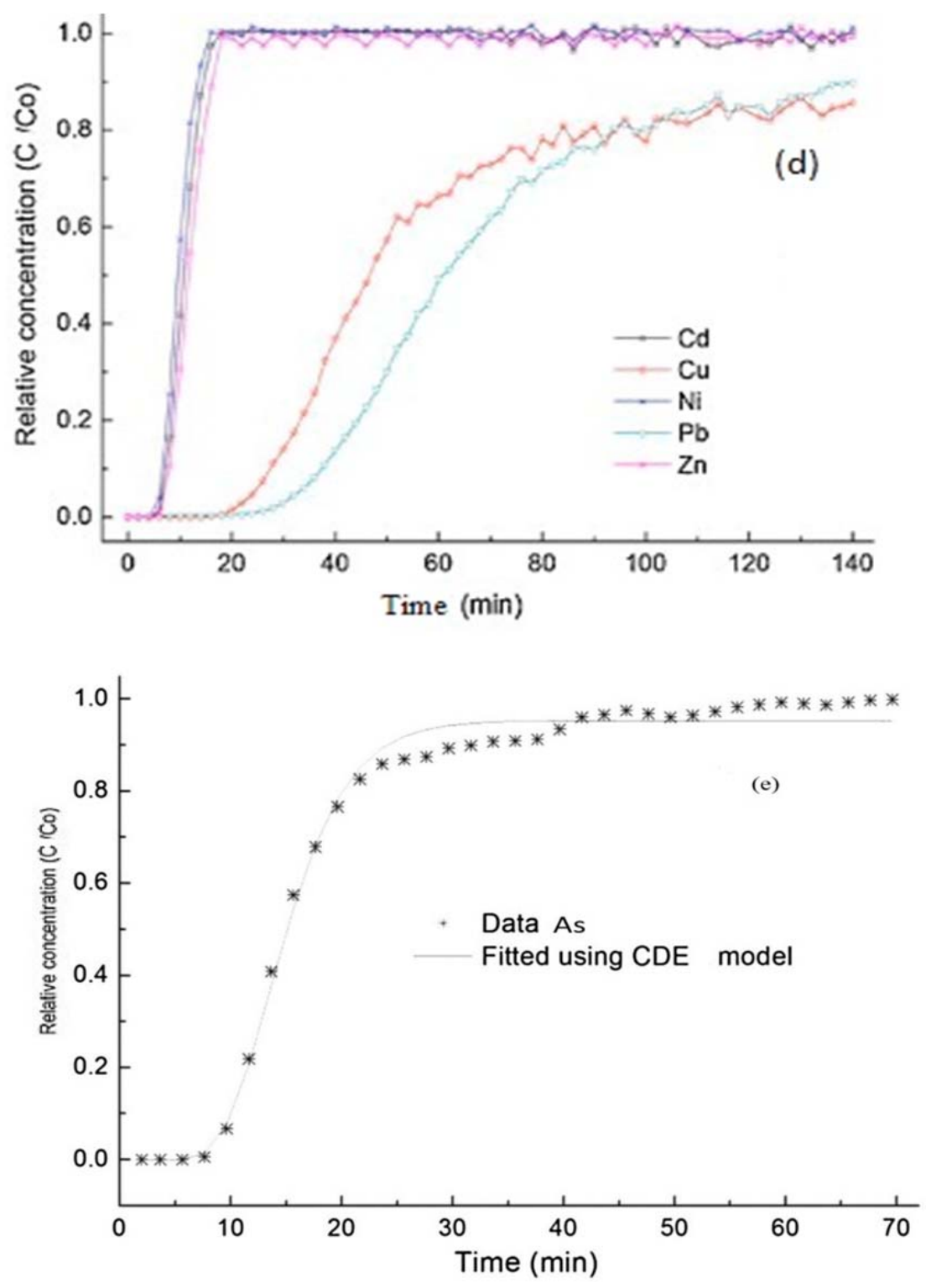

Figure 5. Removal and transport of metals in the fixed-bed column and breakthrough curve. (a). Typical location of the breakthrough point; (b). $\mathrm{Pb}^{2+}$ removal by $\mathrm{BC}$ and $\mathrm{H}_{2} \mathrm{O}_{2}$ modified $\mathrm{BC}(\mathrm{mBC})$ column (modified from Xue et al., 2012); (c). $\mathrm{Cd}^{2+}, \mathrm{Cu}^{2+}, \mathrm{Ni}^{2+}$ and $\mathrm{Pb}^{2+}$ removal by $\mathrm{mBC}$ column (modified from Xue et al., 2012); (d). Alkali modified BC (modified from Ding et al., 2015); (e). Iron impregnated BC (modified from Hu et al., 2015). 


\section{Table 1}

Functional groups present on biomass, BC, modified or impregnated BC surfaces inferred from FTIR spectra analysis.

\begin{tabular}{|c|c|c|c|c|c|}
\hline \multicolumn{4}{|c|}{ Wave number $\left(\mathrm{cm}^{-1}\right)$} & \multirow{2}{*}{ Characteristics vibrations (functionality) } & \multirow[t]{2}{*}{ Reference } \\
\hline Range & Raw biomass & $\mathrm{BC}$ & Modified BC & & \\
\hline \multirow[t]{2}{*}{$3800-3100$} & & & 3135,3650 & $\mathrm{~N}-\mathrm{H}$ stretching of primary amide & {$[12,33]$} \\
\hline & $\begin{array}{l}3324,3418 \\
3428-3437\end{array}$ & $\begin{array}{c}3056,3350,3351,3419,3418-3427,3428- \\
3437,3430,3431,3436,3437,3442,3448 \\
3756 \\
3426\end{array}$ & $\begin{array}{c}3322, \text { 3400, } 3424, \mathbf{3 4 0 9 - 3 4 2 7 , 3 4 3 1} \\
3434,3437,3448,3753 \\
3409,3429,3432,3437\end{array}$ & $\begin{array}{c}\text {-OH stretching/ isolated or exchangeable; stretching of } \mathrm{N}-\mathrm{H} \text { and } \\
\mathbf{O}-\mathrm{H} \text { group due to formation of } \mathrm{NH}_{3}, \text { phenol }-\mathrm{OH}, \boldsymbol{a m i n} \mathrm{N}-\mathrm{H} \\
\text { stretch } \\
-\mathrm{OH} \text { stretching of acid and methanol }\end{array}$ & $\begin{array}{l}{[6,29,32,33,40,46} \\
50,55,61,67,71] \\
{[25]}\end{array}$ \\
\hline \multirow[t]{2}{*}{$3000-2800$} & $\begin{array}{l}2923,2920- \\
2929,2922\end{array}$ & 2920-2920, 2923, 2933; & $\begin{array}{l}2898,2920,2922,2923,2924,2926 \\
2927,2929,2930,2934,2976\end{array}$ & - $\mathrm{CH}$ stretching vibration of asymmetric aliphatic $-\mathrm{CH},-\mathrm{CH}_{2}$ and - & $\begin{array}{c}{[3,29,32,40,42,55} \\
59,70]\end{array}$ \\
\hline & 2855 & 2835,2856 & $2810,2831,2849,2850,2855-2857$ & $\begin{array}{l}\mathrm{CH} \text { stretching vibration of symmetric aliphatic of }-\mathrm{CH},-\mathrm{CH}_{2} \text { and }- \\
\qquad \mathrm{CH}=\mathrm{O} \text { i.e. carbonyl bond group }\end{array}$ & $\begin{array}{c}3,29,32,40,59,69,70 \\
72] \\
{[42]}\end{array}$ \\
\hline \multirow{2}{*}{$2380-2100$} & & & 1700,2340 & $-\mathrm{NH}$ of primary amines & [67] \\
\hline & & & 2121, 2300 & -CH bending, ketene or ketone & {$[29,40]$} \\
\hline $1760-1700$ & $1701-1727,1757$ & $1727-1701$ & $1700,1704,1713,1720,1721,1742$ & $\mathrm{C}=\mathrm{O}$ stretching including ketone, carboxylic acid, ester, anhydride & {$[8,36,40,61,69]$} \\
\hline \multirow[t]{5}{*}{$1660-1400$} & & & $1600-1586, \mathbf{1 6 4 7}, 1653$ & $\begin{array}{c}\text { Oxime } \mathrm{C}=\mathrm{N}-\mathrm{OH} \text {, pyridine } \mathrm{C}-\mathrm{N} \text { and } \mathrm{C}=\mathrm{O} \text { stretching, } \mathrm{N}-\mathbf{H} \text { bending } \\
\text { vibrations }\end{array}$ & {$[3,12,72]$} \\
\hline & & 1640 & 1630,1640 & $-\mathrm{OH}$ and $\mathrm{C}=\mathrm{O} ; \mathbf{C}-\mathbf{C l}$ & {$[6,33]$} \\
\hline & $\begin{array}{l}\mathbf{1 5 5 2 ,}, 1580 \\
1604, \mathbf{1 6 2 0}\end{array}$ & 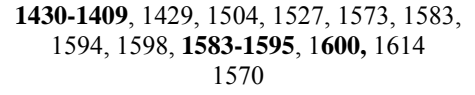 & $\begin{array}{c}\text { 1409-1430, } 1427-1432, \mathbf{1 4 1 5}-\mathbf{1 5 8 5} \\
\text { 1600, } 1611,1614,1620 \\
\mathbf{1 5 4 0}, 1559\end{array}$ & $\begin{array}{c}\mathrm{C}=\mathrm{O} \text { stretching vibration of- } \mathrm{COOH} \text { group; } \mathrm{C}=\mathrm{C} \text { vibration } \\
-\mathrm{NH} \text { stretching of primarily amide }\end{array}$ & $\begin{array}{c}{[33,40,42,50,55,59} \\
72] \\
{[3,29]}\end{array}$ \\
\hline & 1438 & 1439 & & In plane $-\mathrm{OH}$ bending $\& \mathrm{C}-\mathrm{O}$ stretch of dimers & [40] \\
\hline & & 1404 & 1404, 1420 & COO-/ -CONH-, Lactone stucture & {$[6,29,33]$} \\
\hline \multirow[t]{3}{*}{$1400-1300$} & $\begin{array}{l}1398 \\
1386\end{array}$ & $\begin{array}{l}1357, \begin{array}{l}1355-1369 \\
1383\end{array}\end{array}$ & 1394,1397 & $\begin{array}{l}-\mathrm{CH}_{3} \text { deformation } \\
\mathrm{O}=\mathrm{C}=\mathrm{O} \text { group }\end{array}$ & $\begin{array}{l}{[12,40,42]} \\
\quad[50]\end{array}$ \\
\hline & 1377 & 1375 & $1375-1377,1382,1376$ & -OH, - $\mathrm{CH}$ bending of hydrocarbon, acid, phenol, olefin and alcohol & {$[25,70]$} \\
\hline & 1310,1368 & & $1302,1328,1350$ & Single and double bond species of $-\mathrm{OH}$ groups, nitro group & {$[25,29,33,40]$} \\
\hline \multirow[t]{2}{*}{$1300-1080$} & $\begin{array}{l}1215-1219 \\
1257-1265\end{array}$ & $1112,1215-1219,1239,1257-1265$ & $\begin{array}{c}1093,1096,1103,1114, \mathbf{1 2 4 2}, 1252, \\
1263\end{array}$ & $\begin{array}{c}\text {-COOH bending vibration, } \mathrm{C}=\mathrm{O} \text { stretching of aryl-alkyl ether } \\
\text { linkage, phenol }\end{array}$ & {$[25,32,42,50,71]$} \\
\hline & 1111,1190 & 1121 & $1100,1101, \mathbf{1 1 0 6}, 1115,1121 ; 1164$ & C-O-C stretching/ bending, Si-O-Si stretch, Si-O-C & {$[6,29,40,59,70,72]$} \\
\hline $1080-980$ & & & $1040,1055,1056, \mathbf{1 0 6 0}$ & C-N, R-O-C/ R-O-CH & {$[59,61,72]$} \\
\hline
\end{tabular}




\begin{tabular}{|c|c|c|c|c|c|}
\hline & & & 999 & -OH bending & {$[40]$} \\
\hline \multirow[t]{3}{*}{$980-800$} & $894-880$ & $753,812,876-877,894-880$ & $809,812,813$ & Aromatic hydrogen deformation & {$[25,29,42]$} \\
\hline & & & $828-826,860$ & $\mathrm{C}-\mathrm{Br}$ and $\mathrm{C}-\mathrm{Cl}, \mathrm{CaCO}_{3}$ & [67] \\
\hline & 806 & 801.7 & 805 & Benzene derivatives, $\mathrm{Si}-\mathrm{O}-\mathrm{Si}$ stretch/ $\mathrm{Si}-\mathrm{O} / \mathrm{Si}-\mathrm{OH}$ vibration & {$[29,40]$} \\
\hline \multirow[t]{3}{*}{$800-600$} & $752-794$ & $752-794$ & & Aromatic $-\mathrm{CH}$ stretching vibration & [42] \\
\hline & & 628 & $472,580-628$ & C-C stretch or Mn-O & [55] \\
\hline & 604,611 & 603 & & C-O-H bending & [40] \\
\hline \multirow[t]{2}{*}{$600-400$} & & 503 & 550,580 & $-\mathrm{CH}$ bending, $\mathbf{F e O}$ & {$[6,40,46]$} \\
\hline & & & $400-500,466$ & $\mathrm{Fe}-\mathrm{O}$ stretch of $\mathrm{Fe}_{2} \mathrm{O}_{3}$ and $\mathrm{Fe}_{3} \mathrm{O}_{4} ; \mathrm{Si}$-O-Si stretch, free $\mathrm{SiO}_{2}$ & {$[29,67,70]$} \\
\hline
\end{tabular}


Table 2

Models and equations used for batch sorption of contaminants by BCs and modified BCs

\begin{tabular}{|c|c|c|}
\hline Model & Equation & $\begin{array}{l}\text { Graphical presentation to } \\
\text { calculate the constant }\end{array}$ \\
\hline Langmuir & $\begin{array}{l}q_{m}=\frac{q_{\max } K_{L} C_{e}}{1+K_{L} C_{e}} \\
\text { Ce }=\text { equilibrium concentration of sorbate }\left(\mathrm{mg} \mathrm{L}^{-1}\right), \mathrm{q}_{\mathrm{m}}= \\
\text { amount of sorbate sorbed }\left(\mathrm{mg} \mathrm{g}^{-1}\right), \mathrm{q}_{\max }=\text { maximum amount } \\
\text { of sorbate sorbed }\left(\mathrm{mg} \mathrm{g}^{-1}\right) \text { and } \mathrm{K}_{\mathrm{L}}=\mathrm{Langmuir}^{-1} \text { constant } \\
\text { related to the energy of sorption }\left(\mathrm{L} \mathrm{mg}^{-1}\right)\end{array}$ & $\frac{C_{e}}{q_{m}}=\frac{1}{q_{\max } K_{L}}+\frac{C_{e}}{q_{\max }}$ \\
\hline Freundlich & $\begin{array}{l}\mathrm{q}_{\mathrm{e}}=\mathrm{K}_{\mathrm{f}} \mathrm{C}_{\mathrm{e}}{ }^{1 / \mathrm{n}} \\
\mathrm{K}_{\mathrm{f}}=\text { sorption capacity }\left(\mathrm{mg} \mathrm{g}^{-1}\right), \mathrm{n}=\text { sorption intensity }\end{array}$ & $\log q_{m}=\log K_{f}+(1 / n) \log C_{e}$ \\
\hline $\begin{array}{l}\text { Pseudo first order } \\
\text { kinetic (PFO) }\end{array}$ & $\begin{array}{l}\frac{d q_{t}}{d t}=k_{1}\left(q_{e}-q_{t}\right) \\
\mathrm{C}_{0}=\text { initial solute concentration }\left(\mathrm{mg} \mathrm{L}^{-1}\right), \mathrm{C}_{\mathrm{t}}=\text { final solute } \\
\text { concentration }\left(\mathrm{mg} \mathrm{L}^{-1}\right) \text { at a given time, } \mathrm{m}=\text { mass of sorbate } \\
(\mathrm{g}), \mathrm{q}_{\mathrm{e}}=\text { amount of sorbate sorbed at equilibrium }\left(\mathrm{mg} \mathrm{g}^{-1}\right), \mathrm{q}_{\mathrm{t}} \\
=\text { amount of sorbate sorbed at time } \mathrm{t}(\mathrm{min})\left(\mathrm{mg} \mathrm{g}^{-1}\right) \text { and } \mathrm{k}_{1}= \\
\text { equilibrium rate constant of PFO sorption }\left(\mathrm{min}^{-1}\right)\end{array}$ & $\ln \left(q_{e}-q_{t}\right)=\ln q_{e}-k_{1} t$ \\
\hline $\begin{array}{l}\text { Pseudo second } \\
\text { order kinetic (PSO) }\end{array}$ & $\begin{array}{l}\frac{d q_{t}}{d t}=k_{2}\left(q_{e}-q_{t}\right)^{2} \\
\mathrm{k}_{2}=\text { equilibrium rate constant of PSO sorption }\left(\mathrm{g} \mathrm{mg}^{-1} \mathrm{~min}^{-1}\right)\end{array}$ & $\frac{t}{q_{t}}=\frac{1}{k_{2} q_{e}^{2}}+\frac{t}{q_{e}}$ \\
\hline
\end{tabular}


Table 3

Adsorption isotherm and kinetic data of BCs and modified BCs for some inorganic ions and organic pollutants removal

\begin{tabular}{|c|c|c|c|c|c|c|c|c|c|c|c|c|c|c|}
\hline & & PSO & & & PFO & & & Langmuir Is & & & Freundlich & therm & & \\
\hline Type of BC & Pollutants & $\begin{array}{c}\mathrm{q}_{\mathrm{e}} \mathrm{cal} \\
\left(\mathrm{mg} \mathrm{g}^{-1}\right)\end{array}$ & $\begin{array}{c}\mathrm{K}_{2}\left(\mathrm{~g} \mathrm{mg}^{-1}\right. \\
\left.\mathrm{min}^{-1}\right)\end{array}$ & $\mathrm{r}^{2}$ & $\begin{array}{c}\mathrm{q}_{\mathrm{e}} \mathrm{cal}^{-1} \\
\left(\mathrm{mg} \mathrm{g}^{-1}\right)\end{array}$ & $\begin{array}{c}\mathrm{K}_{1}\left(\min ^{-}\right. \\
\left.{ }^{\prime}\right)\end{array}$ & $\mathrm{r}^{2}$ & $\mathrm{q}_{\mathrm{m}}\left(\mathrm{mg} \mathrm{g}^{-1}\right)$ & $\mathrm{K}_{\mathrm{L}}\left(\mathrm{Lmg}^{-1}\right)$ & $\mathrm{r}^{2}$ & $\begin{array}{c}\mathrm{K}_{\mathrm{F}}\left(\mathrm{mg}^{1-\mathrm{n}}\right. \\
\left.\mathrm{L}^{\mathrm{n}} \mathrm{gm}^{-1}\right)\end{array}$ & $1 / \mathrm{n}$ & $\mathrm{r}^{2}$ & Reference \\
\hline Hicory BC & $\mathrm{Cd}^{2+}$ & 14.75 & 0.465 & 0.893 & 14.3 & 3.2 & 0.596 & 28.1 & 0.0363 & 0.932 & 1.644 & 0.196 & 0.714 & [83] \\
\hline Hydrogel -BC & $\mathrm{Zn}(\mathrm{II})$ & 30.3 & 0.136 & 0.999 & 0.375 & 0.0369 & 0.594 & 35.75 & 0.174 & 0.994 & 1.51 & 0.413 & 0.933 & [62] \\
\hline $\mathrm{Mg}-\mathrm{BC}$ & $\mathrm{Fe}$ (II) & 18.08 & 0.0239 & 0.999 & & & & 18.6 & 0.21 & 0.932 & 182.9 & 0.327 & 0.982 & [47] \\
\hline HC-SDBS-CNT & Sulfapyridine & 7.52 & 2.41 & 0.638 & 7.36 & 12.94 & 0.524 & 27.9 & 0.13 & 0.894 & 3.98 & 0.61 & 0.891 & [61] \\
\hline BC-SDBS-CNT & Sulfapyridine & 3.86 & 1.34 & 0.811 & 3.87 & 1.24 & 0.664 & 19.36 & 0.02 & 0.889 & 0.87 & 0.65 & 0.908 & \\
\hline $\mathrm{BC}$ & Phenanthrene & 10.4 & 0.402 & 0.999 & 1.93 & 0.076 & 0.859 & 13.5 & 0.00063 & 0.993 & 749 & 0.492 & 0.973 & [50] \\
\hline $\mathrm{G} / \mathrm{BC}$ & Phenanthrene & 13.9 & 0.193 & 0.999 & 3.42 & 0.088 & 0.865 & 25.3 & 0.00015 & 0.99 & 522 & 0.628 & 0.983 & \\
\hline $\mathrm{Mg}(\mathrm{OH})_{2}-\mathrm{BC}$ & Anionic dye & & & & & & & 205.5 & 0.071 & 0.984 & 22.1 & 0.386 & 0.916 & [72] \\
\hline Activated Biochar & Dibromochloropropane & & & & & & & 102 & 0.77 & & & & & [21] \\
\hline $\mathrm{N}-\mathrm{BC}$ & Diclofenac & & & & & & & 231 & 2.67 & 0.99 & & & & [84] \\
\hline $\mathrm{O}-\mathrm{BC}$ & Diclofenac & & & & & & & 124 & 2.25 & 0.997 & & & & \\
\hline $\mathrm{N}-\mathrm{BC}$ & Ibuprofen & & & & & & & 25.3 & -0.903 & 0.929 & & & & \\
\hline $\mathrm{O}-\mathrm{BC}$ & Ibuprofen & & & & & & & 14.6 & -0.635 & 0.91 & & & & \\
\hline $\mathrm{N}-\mathrm{BC}$ & Naproxen & & & & & & & 155 & 3.2 & 0.99 & & & & \\
\hline $\mathrm{O}-\mathrm{BC}$ & Naproxen & & & & & & & 147 & 2.7 & 0.996 & & & & \\
\hline $\mathrm{NH}_{3}-\mathrm{BC}$ & $\mathrm{CO}_{2}$ & & & & & & & 99 & & & & & & [59] \\
\hline $\mathrm{CO}_{2}-\mathrm{BC}$ & $\mathrm{CO}_{2}$ & & & & & & & 95 & & & & & & \\
\hline ZVI- BC & Pentachlorophenol & & & & & & & 10 & & & & & & {$[67]$} \\
\hline $\mathrm{HNO}_{3}-\mathrm{BC}$ & $\mathrm{U}(\mathrm{VI})$ & & & & & & & 210 & & & & & & [71] \\
\hline $\mathrm{BC}$ & Chloramphenicol & & & & & & & & & & 7.17 & 0.79 & 0.98 & [28] \\
\hline $\begin{array}{l}\mathrm{H}_{2} \\
\mathrm{SO}_{4}-\mathrm{BC}\end{array}$ & Chloramphenicol & & & & & & & & & & 1.93 & 0.54 & 0.93 & \\
\hline $\mathrm{NaOH}-\mathrm{BC}$ & Chloramphenicol & & & & & & & & & & 658 & 2.91 & 0.936 & \\
\hline
\end{tabular}

